\title{
GPP \\ ThG NOR \\ You've Got Mail: A Randomised Field Experiment on Tax Evasion
}

\author{
Kristina M. Bott \\ Alexander Cappelen \\ Erik Ø. Sørensen \\ Bertil Tungodden \\ Working Paper \\ 2017-051 \\ $06 / 2017$
}




\title{
You've got mail: A randomised field experiment on tax evasion*
}

\author{
Kristina M. Bott \\ Alexander W. Cappelen \\ Erik Ø. Sørensen \\ Bertil Tungodden
}

April 25, 2017

\begin{abstract}
We report from a large-scale randomized field experiment conducted on a unique sample of more than 15000 taxpayers in Norway, who were likely to have misreported their foreign income. We find that the inclusion of a moral appeal or a sentence that increases the perceived probability of detection in a letter from the tax authorities almost doubled the average self-reported foreign income. The moral letter mainly works on the intensive margin, while the detection letter mainly works on the extensive margin. We also show that the detection letter has large long-term effects on tax compliance.
\end{abstract}

JEL Classification Numbers: C93, D63, H26.

Keywords: Taxation, tax evasion, field experiment.

\footnotetext{
${ }^{*}$ We would like to thank Nadja Dwenger, Uri Gneezy, Espen Moen, David Laibson, Camille Landais, John List, Ragan Petrie, Agnar Sandmo, László Sándor, Emmanuel Saez, Paul Smeets, and Kjetil Storesletten for extremely valuable comments and suggestions; Kenneth Andreassen, Ingvild Holler Deisz, Marta Johanne Gjengedal, Anita Hallenstvedt, Pia Høst, Elin Imsland, Paul-Gunnar Larsen, Dag Løvås, Bente Lundekvam, Sissel Madsen, Gitte Mårtensen, Vibeke Vik Nordang, Elin Aam Svendsen, Irene Søreide, Thomas Tangen, Christine Osen Tefre, Marcus Zackrisson, and others at Norwegian Tax Authority for their assistance in implementing the experiment; and Trine Sivertsen Sommerlade at Bergen Brannvesen and Fredrik Naumann for pictures used in the experimental materials. All authors: The Choice Lab, NHH Norwegian School of Economics. The project was financed by support from the Research Council of Norway, research grant 236995 and the NORFACE Welfare State Future Program, and it was administered by The Choice Lab, NHH Norwegian School of Economics.
} 


\section{Introduction}

A key challenge in all modern societies is to limit tax evasion, which causes large losses in government revenues and create significant unfairness in society. It has for example been argued that the loss of government revenue amounts to 500 billion USD in the US, corresponding to the size of the government deficit, and 11 billion Euros in Greece, corresponding to $30 \%$ of the government deficit (Cebula and Feige, 2012; Artavanis, Morse, and Tsoutsoura, 2015). Tax evasion is particularly difficult to handle when the tax administration has to rely on self-reported data, since taxpayers have an economic incentive to underreport income (Allingham and Sandmo, 1972; Slemrod and Yitzhaki, 2002; Sandmo, 2005). The classical approach to increasing tax compliance has therefore been to reduce the economic incentives for tax evasion, by increasing the detection probability and penalties and collecting more third-party information. In recent years, however, there has been a growing interest in understanding the extent to which moral motivation or more broadly "tax morale" can play a role in increasing tax compliance in society (Slemrod, 2007; Luttmer and Singhal, 2014).

To study the drivers of tax compliance, and in particular the role of moral motivation, we conducted a large-scale field experiment together with the Norwegian tax administration on a unique sample of more than 15000 taxpayers. The sample consisted of taxpayers who were likely to have misreported their foreign income in the previous tax year, but who were not aware of the fact that the Norwegian tax administration had information about this misreporting. Information about foreign income is not included in the pre-populated tax return in Norway and the taxpayers therefore have to self-report this information. Historically, it has been difficult for the tax authorities to verify the self-reported information because they have not had access to third-party reports from foreign countries, but this has changed due to recent international collaboration among tax authorities.

The field intervention consisted of an information letter sent by the tax administration shortly before the taxpayers were to submit their tax return for the previous year, where we randomly assigned taxpayers to receive different versions of a base letter or to a control group that did not receive any letter. The base letter contained information about why and how to report foreign income income and the effect of this letter sheds light on whether the underreporting was driven by a lack of information about tax procedures. The main focus of this study, however, is to identify the causal effects of introducing moral suasion and increasing the perceived detection probability on tax evasion, and thus we manipulate the base letter along each of these two dimensions in additional treatments. We study two versions of moral suasion, a fairness argument and a societal benefits argument for correctly reporting foreign income. To investigate the importance of the detection probability 
for tax evasion, we added information that we believed would make the taxpayers increase their subjective probability of being audited. We study the effect of our treatment manipulations on self-reported foreign income in the following tax return (the follow-up year) and one year later (long term), and also provide additional evidence allowing us to cleanly identify the underlying mechanisms of the treatment effects.

Our main result is that moral suasion has a large and significant effect on selfreported foreign income. As shown in panel A in Figure 11, in the follow-up year, the average self-reported foreign income by the taxpayers who receive one of the moral letters is almost double the amount self-reported by those who receive the base letter. There is no statistically significant difference in the effect of the two versions of the moral letter. We also find a large effect of the detection letter, but the moral letters and the detection letter affect different margins of the taxpayer behavior. As shown in panel B of Figure 11, the detection letter has a large effect on the extensive margin: it increases the share of taxpayers reporting a positive amount from $20 \%$ among those who receive the base letter to $33 \%$ among those who receive the detection letter. In contrast, the moral letters have a minor effect on the extensive margin, but a large effect on the intensive margin: the moral letters significantly increase the self-reported foreign income among the taxpayers who already report some foreign income. Further, we show that the base letter itself has some effect on self-reported foreign income compared to the group that did not receive any letter, but overall, our study suggests that the underreporting is not primarily driven by a lack of knowledge about how to report foreign income.

[ Figure 1]about here. ]

Our findings are robust across different subgroups (age, gender, Norwegian citizenship, socioeconomic status). For all subgroups, we observe that the moral letters and the detection letter increase the level of self-reported foreign income in the follow-up year, where the moral letters typically work on the intensive margin and the detection letter has a strong effect on the extensive margin. Finally, we provide a set of results on the long-term effects of the intervention, where the main insight is that the detection letter has a large effect on the extensive margin even one year after the taxpayer received the letter, while there are no statistically significant longterm effects of the moral letters. These long-term findings suggest that the moral letters mainly worked through making the moral arguments salient when the taxpayer received the letter, while the detection letter caused the taxpayers to update and sustain their beliefs about the detection probability.

Our paper contributes to the growing literature that uses field interventions to study tax compliance (Coleman, 1996; Blumenthal, Christian, and Slemrod, 2001; 
Coleman, 2007; Kleven, Knudsen, Kreiner, Pedersen, and Saez, 2011; Ariel, 2012; Del Carpio, 2013; Fellner, Sausgruber, and Traxler, 2013; Castro and Scartascini, 2015; Fellner et al., 2013; Hallsworth, 2014; Hallsworth, List, Metcalf, and Vlaev, 2017; Dwenger, Kleven, Rasul, and Rincke, 2016).11 Evidence from these experiments on the drivers of tax evasion has been mixed and, in particular, most of the studies have not been able to document that moral suasion may play an important role in reducing tax evasion. We believe that our study has three main strengths that may contribute to explain why we can cleanly identify strong effects of both moral suasion and an increase in the detection probability. First, we consider a sample and situation where there is no third-party reporting and all taxpayers have an opportunity to evade taxes, while some of the previous studies have suffered from a significant part of the sample being restricted by third-party reporting (Kleven et al. 2011). Second, we carefully timed the distribution of the letters such that the taxpayers received them close to the deadline for submitting the tax return, while some of the previous studies have had a significant lag between the field intervention and the moment of decision-making (Blumenthal et al., 2001; Fellner et al., 2013). Third, our experimental design allows for a clean test of whether it is moral suasion or an increase in detection probability that is driving the change in taxpayers' behavior. We compare the effect of the moral letters and the detection letter to the effect of a base letter that only differs along the relevant dimension and we provide additional survey evidence showing that the letters worked as intended. Overall, we therefore believe that our study provides novel, clean and robust evidence of how both moral suasion and an increase in detection probability may contribute to reduce tax evasion. Further, to our knowledge, we provide the first set of field evidence showing that moral suasion and detection probability affect different margins of taxpayer behavior: moral suasion largely affecting the intensive margin, while detection probability largely affecting the extensive margin. Finally, we also add to the existing literature by presenting long-term results on the effects of the field intervention, where we show that only the effect of the Detection treatment is sustained in the long run.

Our results also speak to the growing literature in behavioural economics studying the role of moral motivation. These studies, mostly relying on lab experiments, have documented that moral motivation matters for people when making economic decision (Fehr and Schmidt, 1999; Bolton and Ockenfels, 2000; Konow, 2000; Andreoni and Miller, 2002; Charness and Rabin, 2002; Engelmann and Strobel, 2004; Cappelen, Drange Hole, Sørensen, and Tungodden, 2007; Cappelen, Moene,

\begin{tabular}{l}
\hline \hline${ }^{1}$ There are also interesting studies of tax compliance in the lab (Alm, McClelland, and Schulze || \\
\hline 1992; Bó and Bó, 2009; Lamberton, Neve, and Norton| 2014) and by the use of observational data \\
\hline (Fisman and Wei, 2004; Rincke and Traxler.|2010, Carrillo, Emran, and Rivadeneira, 2012; Casaburi \\
\hline and Troiano, 2016). \\
\hline
\end{tabular}


Sørensen, and Tungodden, 2013; Fehr, Glätzle-Rützler, and Sutter, 2013). Moreover, in a related literature it has been shown that people do not always lie even when they have an opportunity to do so and can gain from it (Gneezy, 2005; Erat and Gneezy, 2012). These lab experimental findings have sometimes been challenged, because they are established in an artificial setting with small stakes (Levitt and List, 2007). We demonstrate that moral motivation not only matters in the lab, but also in field settings involving large stakes: we find that the taxpayers who receive the moral letters on average self-report 1300 USD more in foreign income than individuals who receive the base letter.

The structure of the paper is as follows: Section 2 presents the setting for the field experiment and the sample, while Section 3 provides details of the experimental design. In Section 4, we provide a simple theoretical framework to guide our analysis, while we outline the empirical strategy in Section 5 . Section 6 discusses the results, while Section 7 provides some concluding remarks.

\section{Background and sample}

In this section we first present how taxes are reported in Norway. We then describe the sample of taxpayers in our study.

\subsection{Tax reporting in Norway}

Every year in April, the Norwegian tax administration (NTA) sends pre-populated tax returns for the previous fiscal year to all Norwegian tax residents. The prepopulated tax return constitutes a preliminary tax statement and the taxpayer is required to add any missing information and correct potential mistakes before the end of April. If the taxpayer believes the information in the pre-populated tax return to be correct and complete, he or she is not required to make any changes.

When filing their taxes, taxpayers are reminded to declare all income, both domestic and foreign, earned in the previous fiscal year. The domestic income is typically for the most part included in the pre-populated tax form, based on third-party reporting in Norway, but information about foreign income must be self-reported by the tax subjects. Historically, it has been difficult for the NTA to control if taxpayers correctly report foreign income because there has been limited exchange of information across national tax jurisdictions. Over the last few years, however, tax administrations in a number of countries have increasingly provided information about the income and wealth that tax residents of other countries earn or hold in their countries. As part of this development, the NTA has in recent years received reports from other tax administrations about Norwegian tax residents' income and 
wealth in the respective countries. These reports are referred to as Automatic Country reports from Abroad (ACA; in Norwegian: Automatiske Kontrolloppgaver Utland). The exchange of such reports is a result of bilateral negotiations between national tax authorities, and not all countries exchange this type of information with the NTA.

The NTA received these reports with delay in the period we studied and thus could not include information about foreign income in the pre-populated tax returns. However, the NTA could compare the self-reported foreign income in the domestic tax returns with the foreign income recorded in the ACA-report at a later date, and this comparison forms the basis for our study.

\subsection{The sample}

For the fiscal year 2011, which is the baseline year of this study, the NTA received ACA-reports for around 40000 Norwegian tax residents. The NTA estimated that 17899 of these had self-reported between 2000 NOK and 200000 NOK (equivalent to approximately 350 - 35000 USD in 2011) less in foreign income than stated in the ACA-reports for the income year 2011, and this group was the point of departure of the present study 2 These individuals were not aware of the fact that the NTA had information about their incorrect reporting of foreign income, and the tax authorities did not act on this information until after the taxpayers had self-reported foreign income for 2012, which is the follow-up year in this study. A small subset of the group that self-reported incorrectly was randomly selected to be part of a practical policy experiment that focused on a specific applied question of interest for the tax authorities, while the rest, 15708 individuals, constitute the sample for the present paper $3^{3}$

Table 1 and Table 2 provide two sets of comparisons for the baseline year; a comparison between the general population and the tax subjects with an ACA report about foreign income and a comparison of those who self-reported incorrectly and those who self-reported correctly foreign income. Tax subjects are classified as individuals who self-reporter correctly if they have misreported less than 2000 NOK in the baseline year. From the left part of Table 1, we observe that compared to the general population, the tax subjects with foreign income are more likely to be nonNorwegian citizens, a large share of whom are from other Nordic countries. We also observe that the individuals with foreign income are slightly more likely to be male and self-employed and are on average a few years older than the general population.

\footnotetext{
${ }^{2}$ We had to exclude 137 individuals, for whom the NTA only had incomplete ACA-reports.

${ }^{3}$ The practical policy experiment tested the usefulness of a weblink providing further information about how to report foreign income.
} 
From the right part of Table 1, we observe that those self-reported incorrectly and those who self-reported correctly are very similar on the background characteristics, with the exception of those who self-reported incorrectly on average being older than those who self-reported correctly.

[ Table 1 about here. ]

Table 2 provides descriptive statistics on income, wealth, and misreporting for the baseline year. From panels A and B, we observe that the tax subjects with ACA-reports have more income and wealth than the general population. Those who self-reported incorrectly have lower income than the those who self-reported correctly, while the two groups have the same level of wealth. Those who selfreported incorrectly have the same level of income as the general population in Norway, but significantly more wealth.

[ Table 2]about here. ]

From panels $\mathrm{C}$ and $\mathrm{D}$, we observe that average foreign income in the ACAreports is $44902 \mathrm{NOK}$ and the mean amount misreported is $8866 \mathrm{NOK}$. Those who self-reported incorrectly have significantly more foreign income in the ACA-reports than those who self-reported correctly, 56280 NOK versus 36852 NOK, and selfreport only 51 percent of it to the tax authorities. Those who self-reported correctly report 5049 more than what is stated in the reports from the tax administrations in other countries, which might reflect that the ACA-reports do not capture all foreign income for the tax subjects (both because the ACA-report from each country is likely to be incomplete and because the NTA does not receive information from all tax authorities across the world).

\section{Experimental design}

The basic structure of the experimental design is that all individuals in our sample received the pre-populated tax returns for the follow-up year in week 14 of 2013, and individuals in the treatment arms then received a letter from the Norwegian tax authorities in week 15 about how to handle foreign income in the tax return; see a copy of the base letter in Figure $\mathrm{A} 1$ in the appendix 4

\footnotetext{
${ }^{4}$ Complete translations of all the letters are provided in Appendix B. Our experiment has an intention-to-treat design, since we do not know how many of the taxpayers actually read the letter. The likelihood of reading the letter, however, should not differ across treatments, since there were no treatment differences in the design of the envelopes. To test whether tax subjects read a letter
} 
The individuals could make changes to the pre-populated tax return, including self-reporting of foreign income, until the deadline in week 18. The individuals were randomly allocated into a control group (No letter) or one of three treatment arms (Base treatment, Moral treatments, Detection treatment) 5 The individuals in the control group did not receive any letter from the tax authorities, while the individuals in the different treatment arms received different versions of the base letter. Our main interest is whether receiving such a letter increased the self-reported foreign income for the follow-up year. We also have long-term data that allow us to study whether the letter intervention affected the self-reported foreign income one year later.

\subsection{Base treatment}

Since any letter from the tax authorities may cause a change in behavior for a number of reasons (fear of detection, moral salience, or better knowledge about how to proceed with the reporting), we included a treatment where the tax residents received a letter that only contained general information about how to self-report foreign income (Base treatment) ${ }^{6}$ The letter consists of three paragraphs, the first explaining why the reader receives this letter. It refers to the fact that the Norwegian economy is becoming more international, and that an increasing number of taxpayers has income from abroad. The taxpayer is then told that the NTA would like to inform him or her about how this type of income is taxed and how it should be reported.

The second paragraph of the letter states that all Norwegian tax residents are liable to pay taxes to Norway on all income and assets, even on foreign income and foreign assets unless otherwise specified in Norway's tax treaties with other

from the tax authorities, the NTA conducted an independent survey where they sent out a version of the base letter to 100 randomly selected taxpayers not taking part in this study. At the end of the first paragraph of this letter, the NTA told the taxpayer that they had been selected to test whether individuals actually read letters from the NTA, and therefore were asked to confirm that they had read the letter by sending an sms to the NTA with the code provided in the letter. $29 \%$ of the recipients of the letter confirmed that they had received it. The NTA then attempted to call the individuals who had not responded and managed to get in touch with $63 \%$ of them (with the restriction that they made a maximum of six attempts): $37 \%$ confirmed that they had read the letter, $3 \%$ confirmed that they had received it, but not read it, $19 \%$ stated that they had not received it, and $4 \%$ stated that they were not sure whether they had received it.

${ }^{5}$ As shown in Table A1 in Appendix A, the treatments are balanced on the background variables.

${ }^{6} \mathrm{We}$ had two different versions of the base letter, one using active language, thus, addressing the reader as "you", and another using passive language (Bryan, Adams, and Monin, 2012). We do not find an economically or statistically significant difference between these two versions of the base letter on the amount self-reported $(p=0.775)$ or the share of individuals self-reporting a positive amount $(p=0.884)$, and thus do not differentiate between them in the following analysis. 
countries. This paragraph also provides a link to the website of the Norwegian tax administration and a phone number to a call centre in the tax administration established for the purpose of this study. $]^{7}$ The final paragraph informs about how to proceed after having received the pre-populated tax returns, and adds a web-link providing further information about how to file the Norwegian tax return.

The Base treatment allows us to study whether lack of information about how to report foreign income is a main driver of the observed underreporting of foreign income. It is, however, important to note that the treatment difference between the Base treatment and the No letter group provides an upper bound estimate of the role of information, since the base letter may also trigger other mechanisms among the taxpayers (including fear of detection and moral salience).

\subsection{Moral and detection treatments}

To identify as cleanly as possible the causal effects of introducing moral suasion and increasing the perceived detection probability, we manipulated the base letter along each of these two dimensions in additional treatments. The treatment manipulations only introduced minor changes in the first paragraph of the letter; the rest of the letter was identical to the base letter.

We studied two types of moral appeals. In the Fairness treatment, the letter introduced a fairness argument for reporting foreign income correctly, by including a sentence that reminded the taxpayers of the fact that most Norwegians report the income earned in Norway correctly. $]^{8}$ Specifically, the following two sentences were added to the end of the first paragraph: "The great majority report information about their income and assets in Norway correctly and completely. In order to treat all taxpayers fairly, it is therefore important that foreign income and foreign assets are reported in the same manner."

In the Societal Benefits treatment, the letter introduced a societal benefits argument for reporting foreign income correctly, by including a sentence that reminded the taxpayers about the benefits to society resulting from taxation: "Your tax pay-

\footnotetext{
${ }^{7}$ In order to standardize the answers to the callers, the NTA provided the phone operators with a script of potential questions and answers. The phone operators were not aware of the call centre facilitating a field experiment, they only knew that the authorities had sent out different letters to different individuals. In Table A2 in Appendix A, we provide an overview of the activity at the call center. 5\% of the individuals receiving a letter approached the call centre, mainly asking questions about why they had received the letter and how to report foreign income. Significantly more individuals in the Detection treatment used the call centre than in the Base treatment (13.1\% versus 3.6\%, $p<0.001$ ), while we see no difference between the Moral treatments and the Base treatment (3.7\% called in the Moral treatments, $p=0.710$ ).

${ }^{8}$ Almost all income earned in Norway is third-party reported to the tax authorities, as in the other Scandinavian countries; see also Kleven et al. (2011); Kleven (2014).
} 
ment contributes to the funding of publicly financed services in education, health and other important sectors of society". 9 In two additional treatments, we visualised the societal benefits from taxation by adding an attachment illustrating publicly financed services in health, education, infrastructure, and research; see Figure B6 in Appendix A. In one treatment, the attachment was combined with the base letter, in another treatment it was combined with the societal benefits letter.

In the Detection treatment, the letter aimed to increase the perceived detection probability of the tax subject. We replaced the first sentence in the base letter: "The Norwegian economy is becoming more internationalised, and an increasing number of Norwegian taxpayers receive income and have assets abroad" with the sentence: "The tax administration has received information that you have had income and/or assets abroad in previous years". The basic idea behind this treatment manipulation was that providing information about the tax authorities' knowledge about the individual activities abroad in previous years would make the tax subjects update their subjective beliefs about the likelihood of being audited in the coming fiscal year.

Table 3 provides an overview of the different treatment arms in the experiment. The experimental design allows for the following two main comparisons to study the drivers of the misreporting of foreign income:

- The role of moral motivation: The comparison between the Moral treatments and the Base treatment identifies the causal effect of moral suasion on taxpayer behavior.

- The role of the detection probability: The comparison between the Detection treatment and the Base treatment identifies the causal effect of increasing perceived detection probability on taxpayer behavior.

When interpreting these treatment comparisons, we make two assumptions. First, we assume that the moral letters only manipulate the moral dimension relative to the base letter; second, we assume that the detection letter only manipulates the perceived detection probability relative to the base letter. We tested these assumptions in an independent survey, where, as shown in Table A4 in Appendix A, we find support for the letters working as intended. Importantly, we find no evidence of the moral letters increasing the perceived detection probability among the recipients of the letters.

\footnotetext{
${ }^{9}$ This sentence may trigger a reciprocity motive for tax compliance, where individuals become more willing to pay taxes because they recognize it as an exchange for benefits that the state provides (Fehr and Gächter, 1998; Luttmer and Singhal, 2014).
} 


\section{Theoretical framework}

We here provide a simple model of taxpayer behavior to guide our analysis and the interpretation of the results, building on Cappelen et al. (2007); Sandmo (2012) .

Assume that the taxpayer has (only) foreign income $y$ and self-reports $r$. The tax on foreign income is $t$ and the penalty on misreported income, if detected, is $\tau$. After tax income is $Y=y-t r$ if not detected and $Z=y-t r-\tau(y-r)$ if detected. Let us assume that the taxpayer has the following expected utility function:

$$
E U(r ; \cdot)=p u(Z)+(1-p) u(Y)-\beta(y-r)^{2},
$$

where $p$ is the subjective probability of being detected and $\beta \geq 0$ is the weight attached to the moral cost of misreporting. It follows straightforwardly that the interior solution for the taxpayer is given by:

$$
r=y-\frac{\Delta u^{s}(r, t, \tau, p)}{2 \beta},
$$

where $\Delta u^{s}(r, t, \tau, p)=(\tau-t)(1-p) u^{\prime}(Y)-p t u^{\prime}(Z)$. The second term in the first order condition captures the trade-off that determines the level of misreporting. The nominator represents the costs in selfish terms of deviating from what would have been reported if $\beta=0$ (since the optimal solution for such an individual would be characterized by $\left.\Delta u^{s}(r, t, \tau, p)=0\right)$, while the denominator shows the relative importance assigned to selfish versus moral costs. In the case where the taxpayer only cares about the moral costs $(\beta \rightarrow \infty)$, the optimal choice is to self-report the foreign income correctly. More generally, the extent of underreporting will depend on the tax parameters, the shape of the utility function, the subjective detection probability, and the importance assigned to the moral cost of misreporting.

The Moral treatments and the Detection treatment aim to increase the weight attached to the moral costs of misreporting $(\beta)$ and to the subjective detection probability $(p)$, respectively, and thereby to increase the self-reported foreign income $(r)$. We do not expect the moral letters permanently to change the moral motivation of the taxpayers, but they may increase the weight attached to the moral cost of misreporting by making the moral argument more salient. The Detection treatment provides new information to the taxpayers which should make them update their subjective beliefs about the likelihood of being detected. Both treatments may work on both the intensive and the extensive margin: The treatments may cause an increase in the self-reported foreign income among the taxpayers who are at an interior solution (the intensive margin) and an increase the share of individuals who actually report some foreign income (the extensive margin). 


\section{Data and empirical strategy}

We here provide an overview of the data and the empirical strategy for the main analysis and the heterogeneity analysis.

\subsection{Data}

The analysis uses data from the administrative records of the NTA. The main outcome variable of interest is self-reported foreign income in the tax return for 2012 (follow-up year) and 2013 (long term). Further, we use the ACA-reports submitted to the NTA from 17 countries to calculate an estimate of the total foreign income for each individual ${ }^{10}$ The administrative records also include data on age, gender, Norwegian citizenship, income, and wealth.

\subsection{Empirical strategy}

In the analysis, our main regression specification is:

$$
y_{i, t}=\alpha+\sum_{l \in L} \beta_{l} d_{i l}+\delta y_{i, b}+\gamma \mathbf{x}_{i}+\varepsilon_{i}
$$

where $y_{i, t}$ is self-reported foreign income for individual $i$ in year $t$. We let $l$ index a treatment in the set of treatments $L$, where $d_{i l}$ is an indicator variable for whether individual $i$ is in treatment $l ; y_{i, b}$ is the self-reported foreign income in the baseline year, and $\mathbf{x}_{i}$ is a vector of background variables (including age, gender, Norwegian citizenship, and a measure of socio-economic status defined by income and wealth). We report the specification where the Base treatment is the omitted category. The estimated causal effect of treatment $l$ relative to the Base treatment is then given by the estimated $\beta_{l}$ coefficient.

We report both regressions where we pool all the Moral treatments, which provides us with an estimate of the average causal effect of the moral treatments relative to the baseline, and regressions where we estimate separately the causal effects of the fairness letter and the social benefits letter. Further, we report regressions where we pool all the treatment arms and define receiving a letter as the omitted category, which provides us with an estimate of the average causal effect of receiving any one of the letters from the tax authorities. For all specifications, we report estimates for regressions both with and without the background variables.

\footnotetext{
${ }^{10}$ According to our agreement with the NTA, we are not allowed to list the countries providing ACA-reports to the NTA.
} 
The average causal effect is a combination of the effect on the extensive margin (causing people who would not have reported any foreign income without the letter to report some amount) and the effect on the intensive margin (causing people who would have reported some foreign income without the letter to report more). We study the effect on the extensive margin by the same regression as in equation 3. where the dependent variable is an indicator variable for self-reported foreign income in year $t$ being strictly positive. To shed some light on the effect on the intensive margin, we also report the effect on self-reported foreign income conditional on it being positive, but it is important to keep in mind that this conditional variable is determined both by the effect on the intensive margin and the effect on the share of taxpayers who actually self-report positive foreign income.

To study whether there are large differences in how the treatments affect the participants, we also conduct an heterogeneity analysis using the background variables age, gender, Norwegian citizenship, and socio-economic status. In this analysis, we take the regression specification where we have pooled the Moral treatments as the point of departure. For each background variable, we partition the set of participants $I$ into $G$ and $I \backslash G$, with $g_{i}$ as an indicator variable for whether individual $i$ is a member of $G$. To illustrate, if the relevant background variable is age, then we partition the set of participants into two subsets, those who are below and above 60 years. The indicator variable would then take the value one if the taxpayer is above those who are 60 years. In each case, we interact the indicator variable with the treatment indicator $d_{i l}$,

$$
y_{i, t}=\alpha+\beta d_{i l}+\theta g_{i} d_{i l}+\lambda g_{i}+\delta y_{i, b}+\gamma \mathbf{x}_{i}+\varepsilon_{i} .
$$

The estimation sample is the participants in the $l$ treatment and in the Base treatment. With this specification, the estimated treatment effect of being in treatment $l$ for individuals in the group $G$ is $\beta+\theta$, while it is $\beta$ for individuals in group $I \backslash G$. Now $\theta$ is the estimated difference in treatment effect between the two groups, and it provides the basis for a statistical test of whether the estimated heterogeneity is statistically significant. The level effect on the self-reporting behavior of belonging to the group $G$ is $\lambda$.

\section{Results}

In this section, we start out by examining how the treatments affected average selfreporting behavior in the follow-up year, before turning to an heterogeneity analysis of the treatments effects. In the final part, we report on long-term effects of the intervention. 


\subsection{Main analysis}

We find significant underreporting of foreign income also in the follow-up year. In our sample, 78 percent of the taxpayers had foreign income recorded in the ACAreports for the follow-up year, on average 42796 NOK, while only 20.7 percent of them self-reported to have foreign income, on average 15485 NOK. We now study whether the different letters caused the taxpayers to self-report more of their foreign income.

\section{[ Table 4 about here. ]}

In Table 4, we report regressions on self-reported foreign income in the followup year based on equation 3. Columns (1)-(2) report estimates of the effect of not receiving a letter, where all taxpayers who did receive a letter are pooled together and serve as the reference category. We observe from column (1) that receiving a letter has a large and highly statistically significant effect on self-reported foreign income: it increases by 8875 NOK, more than 100\%, from 8155 NOK in the No letter group to $17030 \mathrm{NOK}$ in the treatment groups combined. As shown in column (2), the finding is robust to the inclusion of background variables on the amount of self-reported foreign income in the baseline year, the amount of foreign income recorded in the ACA-reports, and personal and socio-economic characteristics of the taxpayer $(p<0.001$, column (2)) 11 Thus, we can state our first main result:

Result 1: A letter from the tax authorities has a large and statistically significant effect on the amount of self-reported foreign income.

In columns (3) - (4), we report estimated treatment effects for each of the letters separately, where the base letter now serves as the reference treatment. We observe that the No letter group reports a lower foreign income than the Base treatment group. The estimated effect of the base letter is borderline significant ( $p=0.113$, column (4)), which suggests that the underreporting is partly driven by a lack of information about how to report foreign income.

The estimates for the moral letters and the detection letter identify the causal effects of adding moral suasion and increasing the detection probability. We observe that the effects are large and highly significant for all the three main treatments

\footnotetext{
${ }^{11}$ In panel A in Figure A3 in Appendix A, we show that there is no corresponding increase in the requests for deductions in taxes based on taxes paid abroad; there is no statistically significant differences across treatments in the deduction amount requested $(p=0.551)$.
} 
( $p=0.010$ (Fairness), $p=0.034$ (Societal Benefits), $p=0.028$ (Detection), column (4)) ${ }^{12}$ Moral suasion, in terms of a fairness argument or of making salient societal benefits from taxation, has a strong positive effect on self-reported foreign income of almost the same magnitude as the introduction of information that increases the detection probability. As shown in columns (5) and (6), where we pool the Moral treatments, moral suasion on average causes an increase in self-reported foreign income of almost $70 \%$ ( $p=0.008$, column (6)), while the Detection treatment increases average self-reported foreign income by $80 \%(p=0.028$; column (6)).

Result 2: Including moral suasion or information that increases the detection probability in the letter from the tax authorities has an economically and statistically highly significant effect on the amount of self-reported foreign income.

In Table 5, we study how the letters affect the extensive margin, i.e., the share of taxpayers who reports to have positive foreign income in the follow-up year. In columns (1)-(2), we observe that receiving a letter from the tax authorities has a large effect on the extensive margin. The share of taxpayers that report a positive foreign income increases from $11 \%$ in the No letter group to $22 \%$ in the treatment groups combined, and, as shown in column (2), the effect is robust to the inclusion of the set of background variables ( $p<0.001$, column (2)).

[ Table 5]about here. ]

The treatments, however, affect the extensive margin very differently, as shown in columns (3)-(6). The base letter and the detection letter have a large and statistically significant effect on the extensive margin ( $p<0.001$ (Base), $p<0.001$ (Detection), column (6)), increasing the share of individuals who self-report foreign income from $11.4 \%$ to $20 \%$ and $33 \%$, respectively. In contrast, the Moral treatments do not on average have a significant effect on the extensive margin ( $p=0.122$, column (6)). There is a small effect of the fairness letter $(p=0.007$, column (4)), significantly weaker than that of the detection letter, while there is no effect on the extensive margin of making societal benefits salient $\left(p=0.478\right.$, column (4)) ${ }^{13}$

\footnotetext{
${ }^{12}$ In Table A3 in Appendix A, we report estimates for the different versions of the Societal Benefits treatments (verbal, visual, verbal and visual), where we in all cases observe an increase in selfreported foreign income. We cannot reject that the three versions have the same effect on taxpayer behavior $(p=0.59$, column 2 in Table A3).

${ }^{13}$ In panel $\mathrm{C}$ in Figure $\mathrm{A} 3$ in Appendix A, we show that these results are robust to only considering the effect on the taxpayers that self-report some foreign income but do not request any deductions.
} 
Result 3: The moral letters and the detection letter have very different effects on the extensive margin. The detection letter causes a large and statistically significant increase in the share of individuals who self-report foreign income, while the moral letters on average has no effect on the extensive margin.

In Figure 2, we report average self-reported foreign income for the group that reports a positive amount in each treatment. We observe that the conditional average foreign income reported is about 50\% higher in the Moral treatments than in the Base treatment, while we see no difference between the Base treatment and the Detection treatment. In fact, the conditional average foreign income reported is lower in the Base treatment and the Detection treatment than in the No letter group. When interpreting these comparisons, it is important to keep in mind how the treatments affected the extensive margin, as reported in Result 3 . The moral treatments had a minor effect on the extensive margin, which means that the large increase in the conditional average foreign income can be interpreted as the moral treatments having a significant effect on the intensive margin. The moral treatments thus appear primarily to have motivated taxpayers who already report some foreign income to reduce their misreporting. For the Base and Detection treatments, however, it is harder to identify the effect on the intensive margin, since both these treatments also had a large effect on the extensive margin. The overall effect on the conditional average foreign income is thus a result of two forces potentially working in opposite directions: a selection effect where more individuals report a positive (and possibly small) amount in these treatments, and an effect on the intensive margin.

[ Figure 2]about here. ]

In tables 4 and 5, we observe that the inclusion of the background variables does not change the estimated treatment effects, but some of the variables are predictive for how much is self-reported in the follow-up year. We observe that there is a highly significant positive association between self-reported foreign income at baseline and in the follow-up year: taxpayers who self-report foreign income in the baseline are more likely to self-report foreign income in the follow-up year and the amount self-reported is increasing in the amount they self-reported at the baseline. We also observe that the foreign income recorded in the ACA-reports is positively associated with self-reported foreign income, but we only find a statistically significant relationship at the extensive margin. This may reflect that the level of foreign income in the ACA-reports is a noisy measure of actual foreign income, since these reports only contain information from some countries and may even for these countries have an imprecise measure of the taxpayer's actual income. Interestingly, we find that females and older people tend to report higher levels of foreign income 
and are also more likely to report foreign income, which is consistent with the common finding that these personal characteristics are positively associated with being morally motivated (Andreoni, Erard, and Feinstein, 1998; Cappelen, Nygaard, Sørensen, and Tungodden, 2015). We also observe that individuals with higher income or greater wealth self-report higher foreign income, while we do not find that Norwegian citizens are significantly different in their self-reporting behavior than non-Norwegian citizens.

\subsection{Heterogeneity analysis}

In Table 6, we report estimated treatment effects by subgroup based on equation (4), where we focus on the Moral treatments combined (panel A) and the Detection treatment (panel B) compared to the Base treatment 14 The most striking feature of this analysis is the consistency in the estimated treatment effects: for all subgroups, we observe that the moral letters and the detection letter increase the level of self-reported foreign income. Not surprisingly, since we here look at smaller subsamples, the estimated effect is not statistically significant for all subgroups, but the robust pattern speaks of these letters having increased self-reported foreign income. Similarly, also for the extensive margin, we find the same patterns across subgroups as in the main analysis: the moral letters have typically a very small or no effect on the extensive margin, while the detection letter has a large and highly statistically significant effect in all subgroups. Overall, the heterogeneity analysis clearly demonstrates that our main findings are robust across subgroups.

\section{[ Table 6]about here. ]}

The fact that the patterns are very similar across subgroups are also reflected in most interactions between treatments and the background characteristics not being significant, with the exception of the interaction between the Moral treatment and high socioeconomic status for amount reported ( $p=0.016$, panel A) and between the Detection treatment and being a Norwegian citizen $(p=0.010$, panel B) or above 60 years $(p<0.001$, panel B).

In the columns "Positive base", we report the interaction between the treatment and an indicator variable for whether an individual self-reported a positive foreign income in the baseline year. In line with the finding that the Moral treatments primarily worked on the intensive margin, we observe in panel A that the effect

\footnotetext{
${ }^{14}$ In Table A5 in Appendix A, we report the heterogeneity analysis for each of the two Moral treatments.
} 
of moral suasion on amount reported is particularly strong for the group that selfreported a positive amount in the baseline year $(p=0.026)$. In contrast, the Moral treatment had only a marginal positive effect on the taxpayers that did not report any foreign income in the baseline year, both in terms of the amount reported and share reporting a positive amount. The pattern is strikingly different for the Detection treatment. In panel B, we observe that the detection letter worked on the extensive margin for both groups, but particularly for those who did not report any foreign income in the baseline year $(p<0.001)$. The Detection treatment also caused an increase in the amount reported in both groups, but this effect is only statistically significant for the taxpayers that did not report any foreign income in the baseline year $(p=0.003)$.

Result 4: The effects of the moral letters and the detection letter are robust across subgroups, with few significant interaction effects between subgroups and treatment. The heterogeneity analysis provides evidence consistent with the moral letters strongly affecting the intensive margin and the detection letter strongly affecting the extensive margin of tax payer behavior.

\subsection{Long-term evidence}

In this part, we study the self-reporting behavior of the taxpayers in our sample in 2014, when they had to self-report their foreign income in the pre-populated tax return for 2013. The deadline was again in week 18, which means their choice of how much to self-report for 2013 happened more than one year after they received the treatment letters.

In the long term, the treatment letters may not only affect the choice of how much to self-report, but also the choice of how much income-generating activity to have abroad. We have shown that the treatment letters in the follow-up year caused more taxpayers to self-report foreign income, which again may imply that they find it less attractive to earn money abroad (because they expect to pay more taxes on foreign income) 15

In Figure 3, we provide an overview of our long-term findings. ${ }^{16}$ In panel A,

\footnotetext{
${ }^{15}$ However, it should be kept in mind the taxpayers received the letter in week 15 of 2013, which means that they only to a limited extent had the opportunity to change the extent to which they earned income abroad in 2013 as a response to the intervention.

${ }^{16}$ Tables A6, A7 and A8 in Appendix A report regression estimates for the long-term analysis. In Table A8 we show that our findings are robust to the removal of the 700 individuals in the No letter group that participated in the independent validation survey of the letters that took place early 2014, and to the removal of the individuals who were most likely to be followed up by the tax authorities in 2013. The latter analysis is based on communication with the NTA, who provided us
} 
we observe that the average self-reported foreign income in the Moral treatments is somewhat higher than in the other treatments, but this difference is not statistically significant. In panel B, however, we observe that even in the long term, there is a large and statistically significant effect of the detection letter on the extensive margin: the share of taxpayers reporting a positive foreign income increases from $25 \%$ in the Base treatment to $32.6 \%$ in the Detection treatment $(p<0.001$, column (6) in Table A7). We also observe that the base letter itself has some effect on the extensive margin in the long-run compared to not receiving a letter $(p=0.070)$, but we do not find any effect of the moral letters $(p=0.684)$.

[ Figure 3 about here. ]

Interestingly, in panel $\mathrm{C}$, we observe that the average self-reported foreign income for the group that reports a positive amount is significantly lower in the Detection treatment than in the other treatments. This is consistent with the detection letter making it less attractive to earn income abroad. In line with what we should expect from panels $\mathrm{A}$ and $\mathrm{B}$, we do not observe any other significant differences in panel C.

Overall, the long-term data provide evidence of the Detection treatment having a lasting effect on taxpayer behavior, by significantly increasing the share of taxpayers who self-report a positive foreign income. In contrast, the Moral treatments primarily seem to have an effect in the short term.

Result 5: The detection letter has a significant long-term effect on the extensive margin, while we do not find any significant long-term effects of the moral letters.

The difference in long-term effects of the detection letter and the moral letters may speak to the underlying mechanisms driving the initial effects observed in the follow-up year. The Moral treatments may primarily have made moral arguments salient when the taxpayers where due to report in the follow-up year, without causing a fundamental change in the preferences of the individual and therefore not changing their long-term behavior. The Detection treatment, on the other hand, may have caused the taxpayers to update their beliefs about the detection probability, and these updated beliefs may have been sustained also in the long term.

with information about their auditing rules. Note that according to our agreement with the NTA, no tax payer was followed up before they had submitted their tax return in the follow-up year. Hence, auditing from the NTA could only potentially affect our long-term findings. 


\section{Conclusions}

Our study shows that tax administrations should consider a rich set of instruments in the fight against tax evasion. A simple and cheap field intervention using letters increased the amount of self-reported foreign income by around 140 million NOK (approximately 25 million USD) in the follow-up year. The intervention also cleanly identified that both moral motivation and economic incentives play a crucial role in shaping taxpayer behavior. In line with the increasing focus among tax administrators on building a tax morale in society (Luttmer and Singhal, 2014), we find a large effect of moral suasion, of the same size as the effect of including a sentence that increases the perceived probability of detection. However, moral appeals and detection probability influence tax behavior in different ways. The moral appeals mainly work on the intensive margin, while increasing the detection probability mainly works on the extensive margin. We also report long-term effects of the intervention, where we show that the detection letter has a large effect on the extensive margin even one year after the taxpayer received the letter, while there are no statistically significant long-term effects of the moral letters.

The long-term findings show that it is important to distinguish between (at least) two different mechanisms when considering how moral suasion may reduce tax evasion. In our study, it appears that moral suasion mainly worked by making the moral argument salient when the taxpayer made the decision of how much to report, but did not work at a more fundamental level by increasing the weight taxpayers assign to the moral cost of misreporting (since there was no effect of the moral letters in the long run). An important question for future research is how tax administrations may contribute to a more fundamental change in the tax morale in society, which most likely requires more extensive interventions than the use of letters. One possibility explored by the Norwegian tax authorities is the launch of training programs targeting adolescents on why society needs taxes. It is by now well established that adolescence is a period of moral development (Almås, Cappelen, Sørensen, and Tungodden, 2010; Fehr et al., 2013), and such interventions thus have the potential to shape the tax morale of future taxpayers.

Our study also demonstrates that the detection probability plays a critical role for tax compliance, and another important avenue for future research would be to study how the moral motive and the detection motive interact in shaping moral behavior. Is there crowding out of moral motivation among taxpayers when tax administrations primarily focus on detection probability and penalty rates (Gneezy and Rustichini, 2000)? Moreover, the fact that the detection letter and the moral letters worked at different margins, shows that the context is important when considering different strategies for increasing tax compliance. A focus on tax morale will only work when tax payers consider it morally wrong to cheat on taxes, but may 
then have significant impact by making tax payers report income that it is impossible to detect for the tax administration. A focus on detection probability is likely to increase tax compliance also in settings where tax subjects are not morally motivated, but may cause a more narrow response where tax payers only start reporting income that they find likely to be detected by the tax administration.

Finally, the study contributes to the broader discussion in economics about the importance of moral motivation, by showing that moral motives not only matters in the lab, but also in field settings involving large stakes. A simple moral message caused the taxpayers to self-report a significantly larger amount of foreign income, which illustrates the power of moral motivation in shaping human behavior.

\section{References}

Allingham, Michael G. and Agnar Sandmo (1972). "Income tax evasion: A theoretical analysis," Journal of Public Economics, 1(3-4): 323-338.

Alm, James, Gary H. McClelland, and William D. Schulze (1992). "Why do people pay taxes?" Journal of Public Economics, 48(1): 21-38.

Almås, Ingvild, Alexander W. Cappelen, Erik Ø. Sørensen, and Bertil Tungodden (2010). "Fairness and the development of inequality acceptance," Science, 328(5982): 1176-1178.

Andreoni, James, Brian Erard, and Jonathan Feinstein (1998). "Tax compliance," Journal of Economic Literature, 36(2): 818-860.

Andreoni, James and John Miller (2002). "Giving according to GARP: An experimental test of the consistency of preferences for altruism," Econometrica, 70(2): 737-753.

Ariel, Barak (2012). "Deterrence and moral persuasion effects on corporate tax compliance: Findings from a randomized controlled trial," Criminology, 50(1): 27-69.

Artavanis, Nikolaos, Adair Morse, and Margarita Tsoutsoura (2015). "Measuring income tax evasion using bank credit: Evidence from Greece," mimeo, University of California, Berkeley.

Blumenthal, Masha, Charles Christian, and Joel Slemrod (2001). "Do normative appeals affect tax compliance? Evidence from a controlled experiment in Minnesota," National Tax Journal, 54(1): 125-138. 
Bó, Ernesto Dal and Pedro Dal Bó (2009). “"Do the right thing:” The effects of moral suasion on cooperation," Journal of Public Economics, 117(1): 28-38.

Bolton, Gary E. and Axel Ockenfels (2000). "ERC: A theory of equity, reciprocity, and competition," American Economic Review, 90(1): 166-193.

Bryan, Christopher J., Gabrielle S. Adams, and Benoît Monin (2012). "When cheating would make you a cheater: Implicating the self prevents unethical behaviour," Journal of Experimental Psychology: General, 142(4): 1001-1005.

Cappelen, Alexander W., Astri Drange Hole, Erik Ø. Sørensen, and Bertil Tungodden (2007). "The pluralism of fairness ideals: An experimental approach," American Economic Review, 97(3): 818-827.

Cappelen, Alexander W., Karl O. Moene, Erik Ø. Sørensen, and Bertil Tungodden (2013). "Needs versus entitlements: An international fairness experiment," Journal of the European Economic Association, 11(3): 574-598.

Cappelen, Alexander W., Knut Nygaard, Erik Ø. Sørensen, and Bertil Tungodden (2015). "Social preferences in the lab: A comparison of students and a representative population," Scandinavian Journal of Economics, 117(4): 1306-1326.

Carrillo, Paul E., M. Shahe Emran, and Anita Rivadeneira (2012). "Do cheaters bunch together? Profit taxes, withholding rates and tax evasion," Working paper.

Casaburi, Lorenzo and Ugo Troiano (2016). "Ghost-house busters: The electoral response to a large anti-tax evasion program," Quarterly Journal of Economics, 131(1): 273-314.

Castro, Lucio and Carlos Scartascini (2015). "Tax compliance and enforcement in the pampas - evidence from a field experiment," Journal of Economic Behavior and Organization, 116(1): 65-82.

Cebula, Richard J. and Edgar L. Feige (2012). "America's unreported economy: measuring the size, growth and determinants of income tax evasion in the U.S." Crime, Law and Social Change, 57(3): 265-285.

Charness, Gary and Matthew Rabin (2002). "Understanding social preferences with simple tests," Quarterly Journal of Economics, 117(3): 817-869.

Coleman, Stephen (1996). "The Minnesota income tax compliance experiment: State tax results," Mimeo, Minnesota Department of Revenue. 
Coleman, Stephen (2007). "The Minnesota income tax compliance experiment: Replication of the social norms experiment," Mimeo, Metropolitan State University.

Del Carpio, Lucia (2013). "Are the neighbours cheating? Evidence from a social norm experiment on property taxes in Peru," Working paper.

Dwenger, Nadja, Henrik Kleven, Imran Rasul, and Johannes Rincke (2016). "Extrinsic and intrinsic motivations for tax compliance: Evidence from a field experiment in Germany," American Economic Journal: Economic Policy, 8(3): 203232.

Engelmann, Dirk and Martin Strobel (2004). "Inequality aversion, efficiency, and maximin preferences in simple distribution experiments," American Economic Review, 94(4): 857-869.

Erat, Sanjiv and Uri Gneezy (2012). "White lies," Management Science, 58(4): 723-733.

Fehr, Ernst and Simon Gächter (1998). "Reciprocity and economics: the economic implications of Homo Reciprocans," European Economic Review, 42(3-5): 845859.

Fehr, Ernst, Daniela Glätzle-Rützler, and Matthias Sutter (2013). "The development of egalitarianism, altruism, spite and parochialism in childhood and adolescence," European Economic Review, 64(1): 369-383.

Fehr, Ernst and Klaus M. Schmidt (1999). "A theory of fairness, competition and cooperation," Quarterly Journal of Economics, 114(3): 817-868.

Fellner, Gerlinde, Rupert Sausgruber, and Christian Traxler (2013). "Testing enforcement strategies in the field: threat, moral appeals and social information," Journal of the European Economic Association, 11(3): 634-660.

Fisman, Raymond and Shang-Jin Wei (2004). "Tax rates and tax evasion: evidence from "missing imports" in China," Journal of Political Economy, 112(2): 471500 .

Gneezy, Uri (2005). "Deception: The role of consequences," American Economic Review, 95(1): 384-394.

Gneezy, Uri and Aldo Rustichini (2000). "Pay enough or don't pay at all," Quarterly Journal of Economics, 115(3): 791-810. 
Hallsworth, Michael (2014). "The use of field experiments to increase tax compliance," Oxford Review of Economic Policy, 30(4): 658-679.

Hallsworth, Michael, John A. List, Robert D. Metcalf, and Ivo Vlaev (2017). "The behavioralist as tax collector: Using natural field experiments to enhance tax compliance," Journal of Public Economics, 148(1): 14-31.

Kleven, Henrik Jacobsen (2014). "How can Scandinavians tax so much?” Journal of Economic Perspectives, 28(4): 77-98.

Kleven, Henrik Jacobsen, Martin B. Knudsen, Claus Thustrup Kreiner, Søren Pedersen, and Emmanuel Saez (2011). "Unwilling or unable to cheat? Evidence from a tax audit experiment in Denmark," Econometrica, 79(3): 651-692.

Konow, James (2000). "Fair Shares: Accountability and Cognitive Dissonance in Allocation Decisions," American Economic Review, 90(4): 1072-1091.

Lamberton, Cait, Jan-Emmanuel De Neve, and Michael I. Norton (2014). "Eliciting taxpayer preferences increases tax compliance," Working Paper.

Levitt, Steven D. and John A. List (2007). "What do laboratory experiments measuring social preferences reveal about the real world?" Journal of Economic Perspectives, 21(2): 153-174.

Luttmer, E. P. and Monica Singhal (2014). “Tax morale," Journal of Economic Perspectives, 28(4): 149-168.

Rincke, Johannes and Christian Traxler (2010). "Enforcement spillovers," Review of Economics and Statistics, 93(4): 1224-1234.

Sandmo, Agnar (2005). "The theory of tax evasion: A retrospective view," National Tax Journal, 58(4): 643-663.

Sandmo, Agnar (2012). "An evasive topic: Theorizing about the hidden economy," International Tax and Public Finance, 19(1): 5-24.

Slemrod, Joel (2007). "Cheating ourselves: The economics of tax evasion," Journal of Economic Perspectives, 21(1): 25-48.

Slemrod, Joel and Shlomo Yitzhaki (2002). "Tax avoidance, evasion, and administration," in Alan J. Auerbach and Martin Feldstein (eds.), "Handbook of Public Economics," volume 3, Elsevier, pp. 1423-1470. 

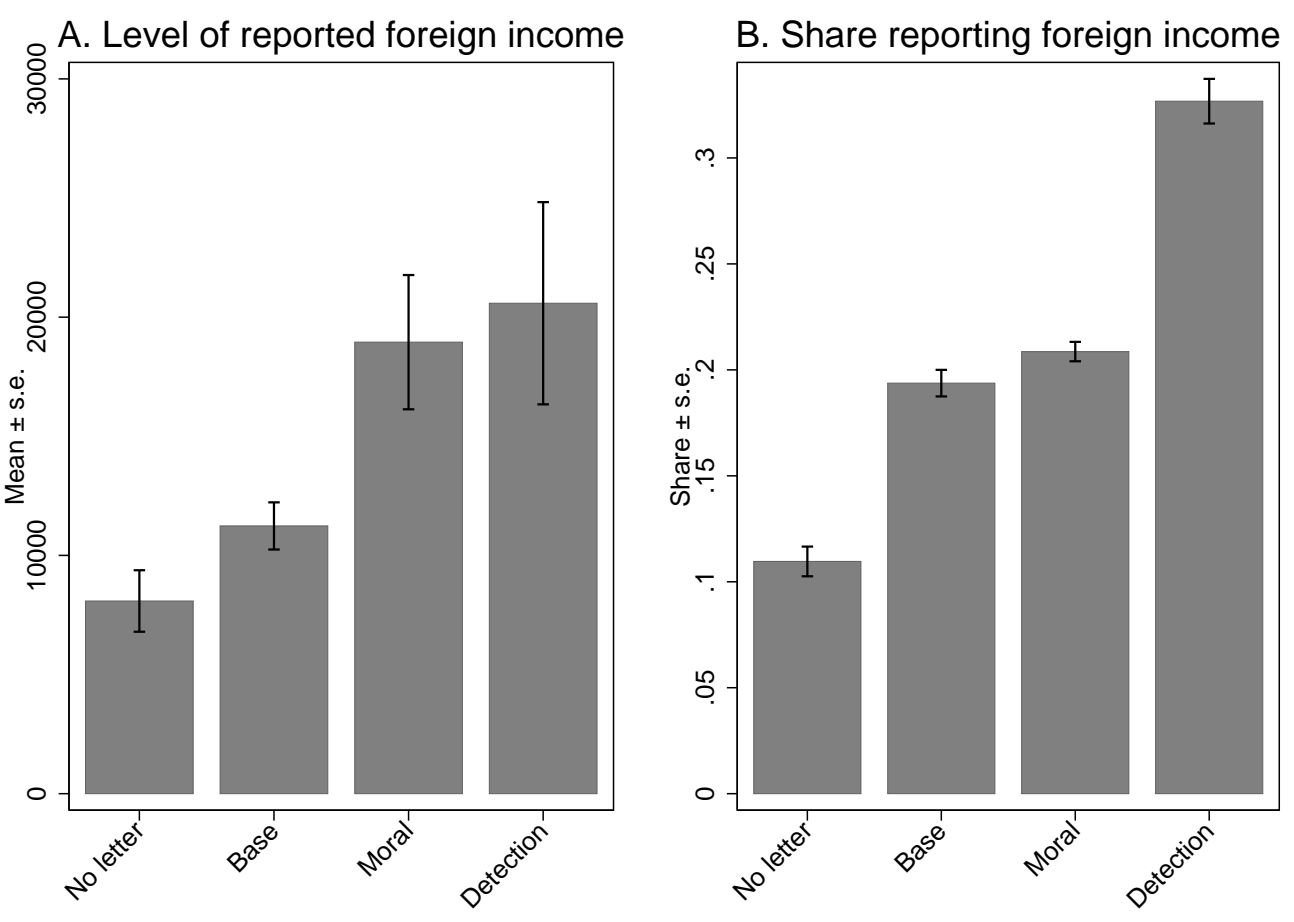

Figure 1: Self-reported foreign income

Panel A shows the average amount of self-reported foreign income (in NOK) and Panel B shows the share of taxpayers who self-report a positive foreign income, by treatment. 


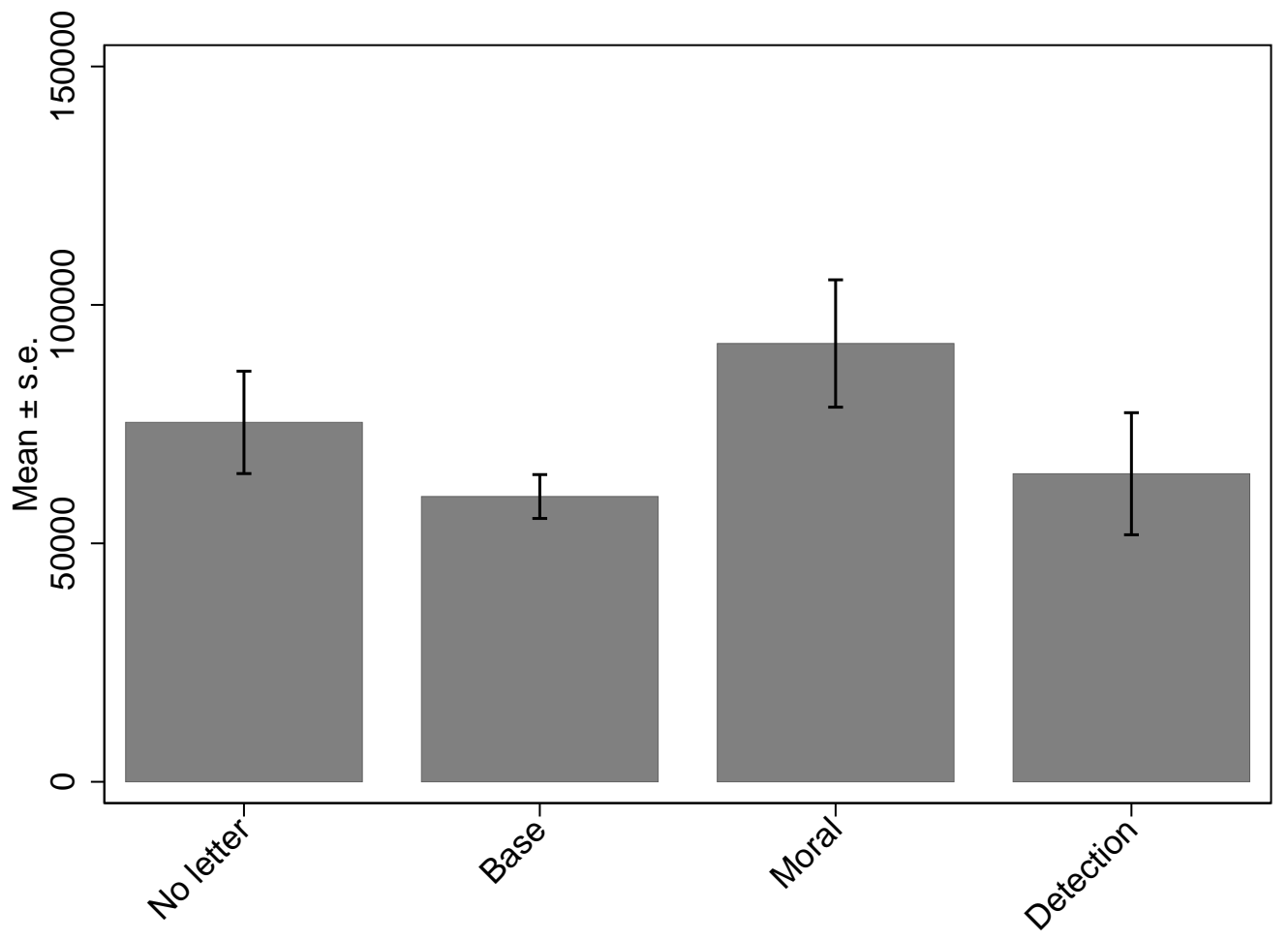

Figure 2: Self-reported foreign income - conditional on it being positive

The figure shows the average amount of self-reported foreign income (in NOK) for the subset of taxpayers that report a positive foreign income. 

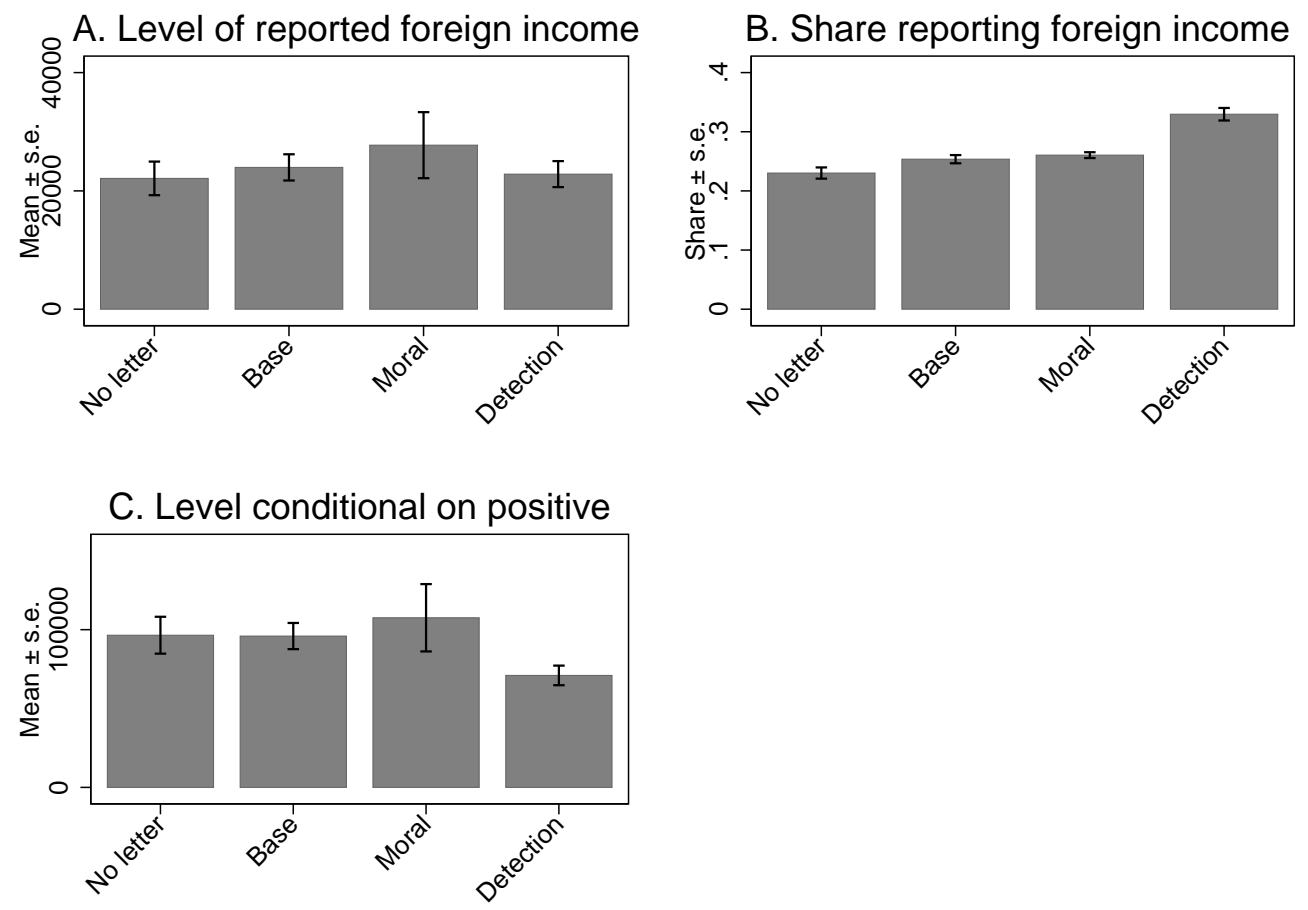

Figure 3: Long-term (2013) self-reported foreign income

The figure shows self-reported foreign income for the tax year 2013, which was self-reported more than one year after the intervention. Panel A shows the average amount of self-reported foreign income (in NOK), Panel B shows the share of taxpayers who self-report a positive foreign income, and Panel $\mathrm{C}$ shows the average amount of self-reported foreign income (in NOK) for the subset of taxpayers that report a positive foreign income. 
Table 1: Descriptive statistics on the samples: General

\begin{tabular}{|c|c|c|c|c|}
\hline & \multicolumn{2}{|c|}{ Samples } & \multicolumn{2}{|c|}{ ACA-report } \\
\hline & $\begin{array}{l}\text { In } \mathrm{ACA} \\
\text { reports }\end{array}$ & $\begin{array}{c}\text { General } \\
\text { population }\end{array}$ & Incorrect & Correct \\
\hline Share Norwegian citizen & 0.522 & 0.836 & 0.550 & 0.503 \\
\hline Share citizen of other Nordic country & 0.456 & 0.039 & 0.431 & 0.474 \\
\hline Share female & 0.445 & 0.502 & 0.455 & 0.437 \\
\hline Mean age & 53.4 & 49.8 & 58.4 & 49.9 \\
\hline Share older than 60 years old & 0.429 & 0.289 & 0.566 & 0.332 \\
\hline Share self-employed & 0.117 & 0.084 & 0.095 & 0.133 \\
\hline Observations & 37897 & 215956 & 15708 & 22189 \\
\hline
\end{tabular}

The general population refers to a 5\% sample of the population in the Norwegian tax records that do not have an ACA-report. For the individuals in the Norwegian tax records that have an ACA-report, "Incorrect" denotes the set of individuals who have self-reported foreign income incorrectly and "Correct" denotes the set of individuals who have self-reported foreign income incorrectly. 
Table 2: Income, wealth, and misreporting in baseline year

\begin{tabular}{|c|c|c|c|c|}
\hline & \multicolumn{2}{|c|}{ Samples } & \multicolumn{2}{|c|}{ ACA-report } \\
\hline & $\begin{array}{c}\text { In ACA } \\
\text { reports }\end{array}$ & $\begin{array}{c}\text { General } \\
\text { population }\end{array}$ & Incorrect & Correct \\
\hline \multicolumn{5}{|c|}{ A. Taxable income: } \\
\hline mean & 360628 & 272616 & 299838 & 403619 \\
\hline$Q_{25}$ & 119834 & 110447 & 97199 & 147551 \\
\hline$Q_{50}$ & 234809 & 215354 & 182845 & 274685 \\
\hline$Q_{75}$ & 419110 & 345076 & 347295 & 458413 \\
\hline \multicolumn{5}{|c|}{ B. Taxable wealth: } \\
\hline mean & 1330938 & 462820 & 1530805 & 1189590 \\
\hline$Q_{25}$ & 0 & 0 & 0 & 0 \\
\hline$Q_{50}$ & 43248 & 63 & 35277 & 35277 \\
\hline$Q_{75}$ & 609583 & 325706 & 577269 & 577269 \\
\hline \multicolumn{5}{|c|}{ C. ACA-reports of foreign income: } \\
\hline mean & 44902 & & 56280 & 36852 \\
\hline$Q_{25}$ & 519 & & 7509 & 105 \\
\hline$Q_{50}$ & 6560 & & 18987 & 868 \\
\hline$Q_{75}$ & 29073 & & 48670 & 12284 \\
\hline \multicolumn{5}{|c|}{ D. Estimate of misreporting: } \\
\hline mean & 8866 & & 28533 & -5049 \\
\hline$Q_{25}$ & 16 & & 4187 & 3 \\
\hline$Q_{50}$ & 985 & & 14209 & 154 \\
\hline$Q_{75}$ & 13556 & & 36732 & 948 \\
\hline
\end{tabular}

Panel A and B refer to (taxable) income and wealth in the baseline year 2011. Panel C shows total foreign income recorded in the ACA-reports, while panel D shows misreported foreign income (calculated by the difference between the foreign income in the ACA-reports and self-reported foreign income). $Q_{x}$ refers to the $x$-percentile in the relevant group. The general population refers to a $5 \%$ sample of the population in the Norwegian tax records that do not have an ACA-report. For the individuals in the Norwegian tax records that have an ACA-report, "Incorrect" denotes the set of individuals who have self-reported foreign income incorrectly and "Correct" denotes the set of individuals who have self-reported foreign income incorrectly. 
Table 4: Treatment effects on self-reported foreign income

\begin{tabular}{|c|c|c|c|c|c|c|}
\hline & (1) & (2) & (3) & (4) & (5) & (6) \\
\hline No letter & $\begin{array}{c}-8874.9^{* * *} \\
(2184.5)\end{array}$ & $\begin{array}{c}-10008.1^{* * *} \\
(2767.4)\end{array}$ & $\begin{array}{l}-3188.0^{*} \\
(1643.1)\end{array}$ & $\begin{array}{l}-4339.1 \\
(2734.8)\end{array}$ & $\begin{array}{l}-3188.0^{*} \\
(1643.1)\end{array}$ & $\begin{array}{l}-4339.6 \\
(2735.2)\end{array}$ \\
\hline Fairness & & & $\begin{array}{l}15158.5^{*} \\
(8860.6)\end{array}$ & $\begin{array}{c}10372.1^{* *} \\
(4041.9)\end{array}$ & & \\
\hline Societal Benefits & & & $\begin{array}{l}5180.9^{* *} \\
(2596.8)\end{array}$ & $\begin{array}{l}6345.5^{* *} \\
(2989.0)\end{array}$ & & \\
\hline Detection & & & $\begin{array}{l}9199.6^{* *} \\
(4385.6)\end{array}$ & $\begin{array}{c}10351.3^{* *} \\
(4702.7)\end{array}$ & $\begin{array}{l}9199.6^{* *} \\
(4385.5)\end{array}$ & $\begin{array}{c}10351.6^{* *} \\
(4702.8)\end{array}$ \\
\hline Moral & & & & & $\begin{array}{l}7671.1^{* *} \\
(3010.7)\end{array}$ & $\begin{array}{c}7350.5^{* * *} \\
(2772.9)\end{array}$ \\
\hline Foreign income baseline & & $\begin{array}{l}0.42^{* *} \\
(0.20)\end{array}$ & & $\begin{array}{l}0.42^{* *} \\
(0.20)\end{array}$ & & $\begin{array}{l}0.42^{* *} \\
(0.20)\end{array}$ \\
\hline ACA-report baseline & & $\begin{array}{l}0.00089 \\
(0.0035)\end{array}$ & & $\begin{array}{l}0.00091 \\
(0.0035)\end{array}$ & & $\begin{array}{l}0.00091 \\
(0.0035)\end{array}$ \\
\hline ACA-report follow-up & & $\begin{array}{c}0.010 \\
(0.0073)\end{array}$ & & $\begin{array}{c}0.010 \\
(0.0073)\end{array}$ & & $\begin{array}{c}0.010 \\
(0.0073)\end{array}$ \\
\hline Female & & $\begin{array}{l}6791.0^{*} \\
(3640.9)\end{array}$ & & $\begin{array}{l}6782.8^{*} \\
(3634.1)\end{array}$ & & $\begin{array}{l}6777.1^{*} \\
(3633.9)\end{array}$ \\
\hline Age $>60 \mathrm{yrs}$ & & $\begin{array}{l}9167.8^{*} \\
(5207.1)\end{array}$ & & $\begin{array}{l}9148.3^{*} \\
(5209.7)\end{array}$ & & $\begin{array}{l}9144.6^{*} \\
(5207.6)\end{array}$ \\
\hline Norwegian citizen & & $\begin{array}{c}2702.2 \\
(3294.8)\end{array}$ & & $\begin{array}{c}2733.2 \\
(3307.6)\end{array}$ & & $\begin{array}{c}2741.5 \\
(3306.1)\end{array}$ \\
\hline High SES & & $\begin{array}{c}4591.3 \\
(5275.6)\end{array}$ & & $\begin{array}{c}4615.8 \\
(5262.7)\end{array}$ & & $\begin{array}{c}4595.0 \\
(5274.6)\end{array}$ \\
\hline Constant & $\begin{array}{c}17029.8^{* * *} \\
(1752.6)\end{array}$ & $\begin{array}{c}-6706.3 \\
(6673.8)\end{array}$ & $\begin{array}{c}11342.9^{* * *} \\
(999.6)\end{array}$ & $\begin{array}{l}-12387.4 \\
(7537.0)\end{array}$ & $\begin{array}{c}11342.9^{* * *} \\
(999.6)\end{array}$ & $\begin{array}{l}-12380.8 \\
(7535.5)\end{array}$ \\
\hline F-test $p$ on Moral treatme & s being equal: & & 0.27 & 0.32 & & \\
\hline Observations & 15708 & 15708 & 15708 & 15708 & 15708 & 15708 \\
\hline$R^{2}$ & 0.000 & 0.230 & 0.001 & 0.231 & 0.001 & 0.231 \\
\hline
\end{tabular}

The table reports regressions based on equation 3 , where the dependent variable is the amount foreign income self-reported for the follow-up year. In columns (1) - (2), the estimated effects are relative to the the pooled sample of all treatment groups; in columns (3)-(6), the estimated effects are relative to the Base treatment. The indicator variables "No letter", "Fairness", "Societal Benefits", and "Detection" take the value one if the taxpayer is in the respective treatment. The indicator variable "Moral" is one if the taxpayer is in the Fairness treatment or the Social Benefits treatment. The reported $F$-test $p$ is for the hypothesis that all Moral treatments have the same effect. Columns (2), (4), and (6) include the following controls: the amount of self-reported foreign income for the baseline year, the amount of foreign income recorded in the ACA-reports for 2011 and 2012, gender, age (an indicator variable taking the value one if the taxpayer is more than 60 years), an indicator variable taking the value one if the tax payer is a Norwegian citizen, and an indicator variable of socio-economic status taking the value one if the taxpayer is in the upper $25 \%$ of the income and wealth distribution in the baseline year. Robust standard errors in parentheses. $\left(^{*}: p<0.1,{ }^{* *}: p<0.05,{ }^{* * *}: p<0.01\right)$. 
Table 5: Treatment effects on self-reporting of any foreign income

\begin{tabular}{|c|c|c|c|c|c|c|}
\hline & (1) & (2) & (3) & (4) & (5) & (6) \\
\hline No letter & $\begin{array}{l}-0.11^{* * *} \\
(0.0079)\end{array}$ & $\begin{array}{l}-0.11^{* * *} \\
(0.0076)\end{array}$ & $\begin{array}{c}-0.086^{* * *} \\
(0.0095)\end{array}$ & $\begin{array}{c}-0.083^{* * *} \\
(0.0091)\end{array}$ & $\begin{array}{c}-0.086^{* * *} \\
(0.0095)\end{array}$ & $\begin{array}{c}-0.083^{* * *} \\
(0.0091)\end{array}$ \\
\hline Fairness & & & $\begin{array}{c}0.031^{* * *} \\
(0.011)\end{array}$ & $\begin{array}{c}0.030^{* * *} \\
(0.011)\end{array}$ & & \\
\hline Societal Benefits & & & $\begin{array}{c}0.0086 \\
(0.0082)\end{array}$ & $\begin{array}{c}0.0056 \\
(0.0079)\end{array}$ & & \\
\hline Detection & & & $\begin{array}{l}0.13^{* * *} \\
(0.012)\end{array}$ & $\begin{array}{l}0.13^{* * *} \\
(0.012)\end{array}$ & $\begin{array}{l}0.13^{* * *} \\
(0.012)\end{array}$ & $\begin{array}{l}0.13^{* * *} \\
(0.012)\end{array}$ \\
\hline Moral & & & & & $\begin{array}{c}0.014^{*} \\
(0.0078)\end{array}$ & $\begin{array}{c}0.012 \\
(0.0075)\end{array}$ \\
\hline Positive foreign income baseline & & $\begin{array}{c}0.16^{* * *} \\
(0.0073)\end{array}$ & & $\begin{array}{c}0.16^{* * *} \\
(0.0073)\end{array}$ & & $\begin{array}{c}0.16^{* * *} \\
(0.0073)\end{array}$ \\
\hline ACA-report baseline & & $\begin{array}{l}0.022^{*} \\
(0.012)\end{array}$ & & $\begin{array}{l}0.022^{*} \\
(0.013)\end{array}$ & & $\begin{array}{l}0.022^{*} \\
(0.013)\end{array}$ \\
\hline ACA report follow-up & & $\begin{array}{c}0.031 \\
(0.023)\end{array}$ & & $\begin{array}{c}0.029 \\
(0.024)\end{array}$ & & $\begin{array}{c}0.029 \\
(0.023)\end{array}$ \\
\hline Female & & $\begin{array}{l}0.052^{* * *} \\
(0.0063)\end{array}$ & & $\begin{array}{l}0.052^{* * *} \\
(0.0063)\end{array}$ & & $\begin{array}{l}0.052^{* * *} \\
(0.0063)\end{array}$ \\
\hline Age $>60$ yrs & & $\begin{array}{c}0.21^{* * *} \\
(0.0075)\end{array}$ & & $\begin{array}{c}0.21^{* * *} \\
(0.0075)\end{array}$ & & $\begin{array}{c}0.21^{* * *} \\
(0.0075)\end{array}$ \\
\hline Norwegian citizen & & $\begin{array}{l}0.00033 \\
(0.0069)\end{array}$ & & $\begin{array}{l}0.00014 \\
(0.0068)\end{array}$ & & $\begin{array}{l}0.00019 \\
(0.0068)\end{array}$ \\
\hline High SES & & $\begin{array}{l}0.037^{* * *} \\
(0.0070)\end{array}$ & & $\begin{array}{l}0.038^{* * *} \\
(0.0070)\end{array}$ & & $\begin{array}{c}0.038^{* * *} \\
(0.0070)\end{array}$ \\
\hline Constant & $\begin{array}{c}0.22^{* * *} \\
(0.0035)\end{array}$ & $\begin{array}{c}-0.0035 \\
(0.0065)\end{array}$ & $\begin{array}{c}0.20^{* * *} \\
(0.0063)\end{array}$ & $\begin{array}{c}-0.029^{* * *} \\
(0.0081)\end{array}$ & $\begin{array}{c}0.20^{* * *} \\
(0.0063)\end{array}$ & $\begin{array}{c}-0.029^{* * *} \\
(0.0081)\end{array}$ \\
\hline \multicolumn{3}{|c|}{ F-test $p$ on Moral treatments being equal: } & 0.038 & 0.021 & & \\
\hline Observations & 15708 & 15708 & 15708 & 15708 & 15708 & 15708 \\
\hline$R^{2}$ & 0.008 & 0.091 & 0.019 & 0.102 & 0.019 & 0.102 \\
\hline
\end{tabular}

The table reports regressions based on equation 3 , where the dependent variable is an indicator variable taking the value one if the taxpayer self-reports any foreign income reported for the followup year. In columns (1) - (2), the estimated effects are relative to the the pooled sample of all treatment groups; in columns (3)-(6), the estimated effects are relative to the Base treatment. The indicator variables "No letter", "Fairness", "Societal Benefits", and "Detection" take the value one if the taxpayer is in the respective treatment. The indicator variable "Moral" is one if the taxpayer is in the Fairness treatment or the Social Benefits treatment. The reported $F$-test $p$ is for the hypothesis that all Moral treatments have the same effect. Columns (2), (4), and (6) include the following controls: an indicator variable taking the value one if the taxpayer self-reported any foreign income for the baseline year, the amount of foreign income recorded in the ACA-reports for 2011 and 2012 (scaled in units of $1000000 \mathrm{NOK}$ ), gender, age (an indicator variable taking the value one if the taxpayer is more than 60 years), an indicator variable taking the value one if the tax payer is a Norwegian citizen, and an indicator variable of socio-economic status taking the value one if the taxpayer is in the upper $25 \%$ of the income and wealth distribution in the baseline year. Robust standard errors in parentheses. $\left({ }^{*}: p<0.1,{ }^{* *}: p<0.05,{ }^{* * *}: p<0.01\right)$. 


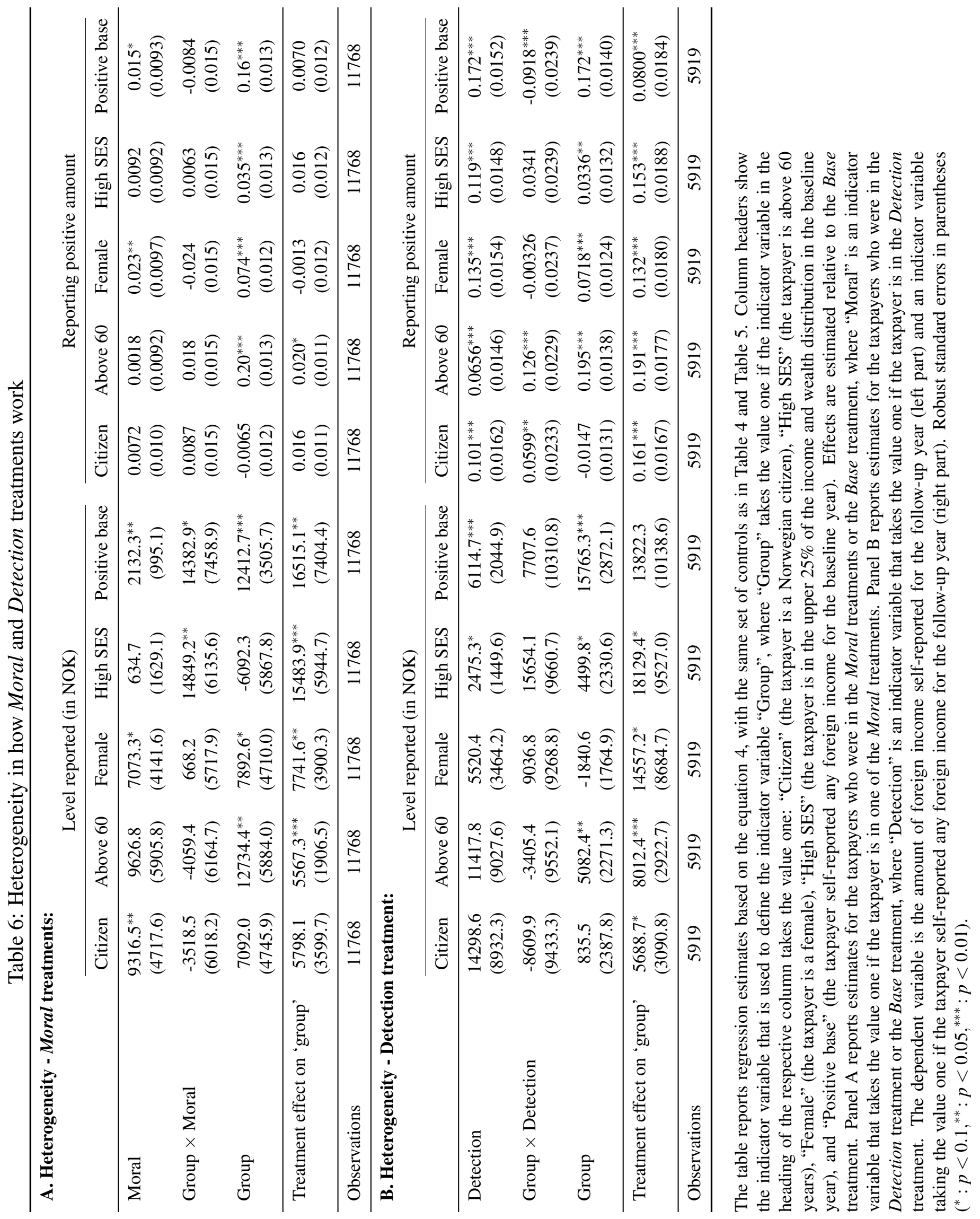




\section{A Appendix for online publication only: Supplemen- tary material}

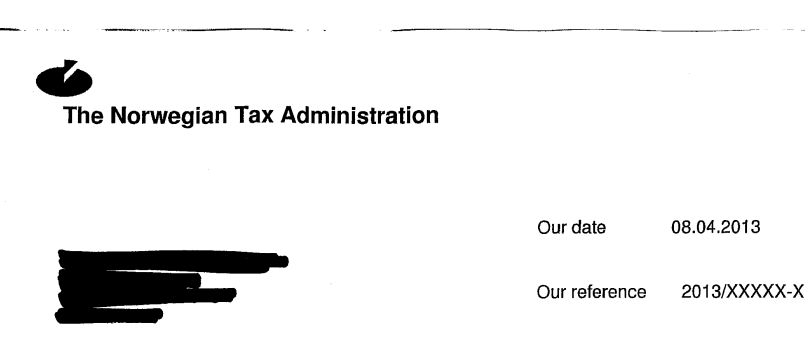

The Norwegian economy is becoming more internationalised, and an increasing number of Norwegian taxpayers receive income and have assets abroad. You are receiving this letter because The Norwegian Tax Administration would like to inform you about how this type of income is taxed and how it should be reported.

If you are a tax resident of Norway, you are liable to pay taxes to Norway even on foreign income and foreign assets, unless otherwise specified in the tax treaties Norway has entered into with other countries. Information about tax treaties and the rules that apply for taxation of foreign income and foreign assets is available at the homepage of The Norwegian Tax Administration www.skatteetaten.no. You can also contact us by telephone 21497394 (opening hours: $08.00-15.30$ ).

When you receive the pre-completed tax return, you must check the information that it contains. If all information is correct and complete, you do not need to make any changes.

The pre-completed tax return will typically not contain information about foreign income and

foreign assets. You therefore need to report all income, all assets and all taxes paid in

foreign countries. More information is available on www.skatteetaten.no/A-rettledninger.

Regards

The Norwegian Tax Administration

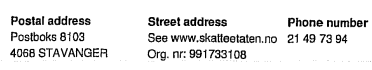

Figure A1: The letter sent in the Base treatment 

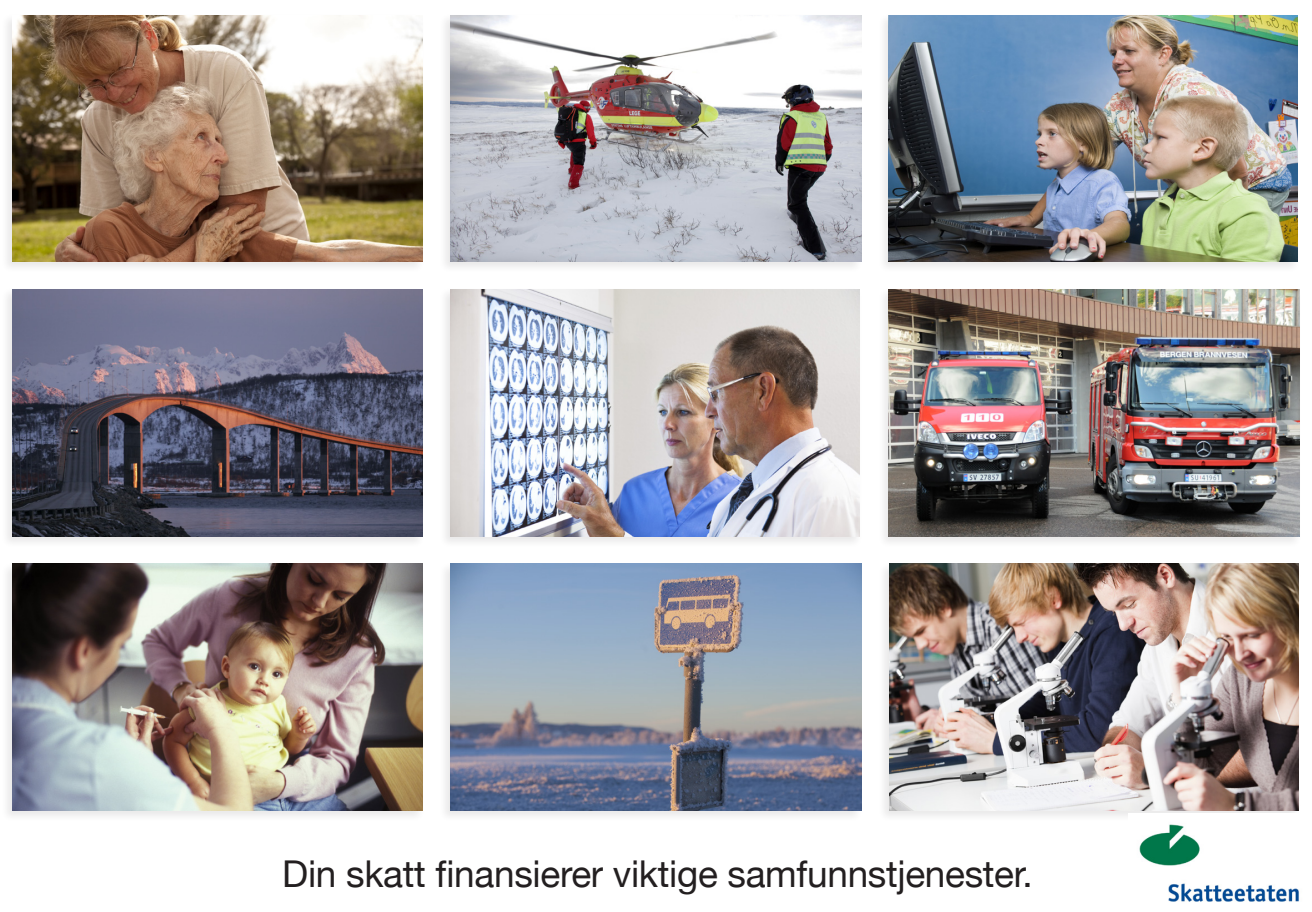

Din skatt finansierer viktige samfunnstjenester.

Skatteetaten

Figure A2: Attachment to Moral (Societal Benefits) treatments.

The attachment included in the versions of the Societal Benefits treatments that included a visual element. The subtitle to the picture states that "Your taxes finance important public services." 

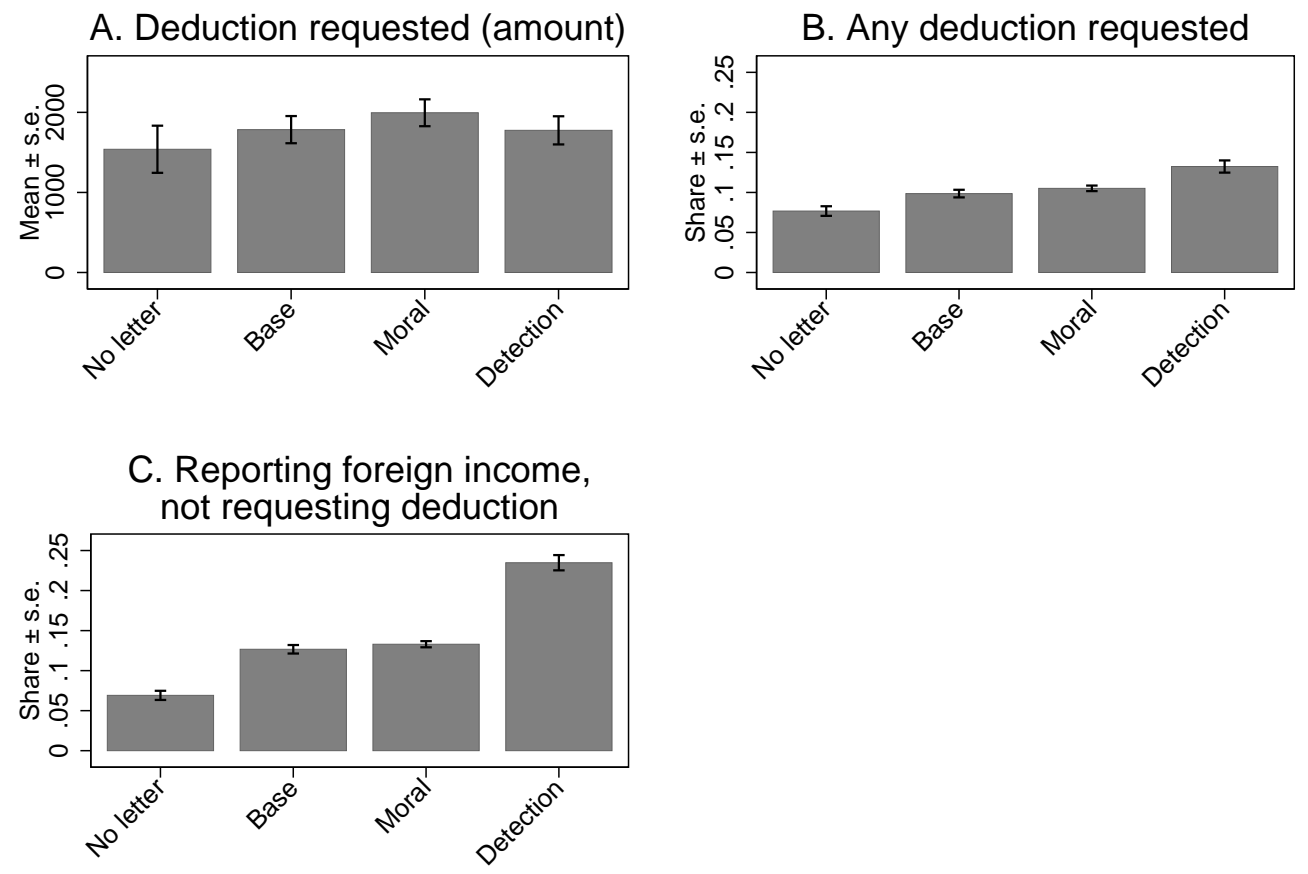

Figure A3: Applications for deductions of taxes paid abroad

The graph shows, for the follow-up year, the average amount of requested deductions in Norwegian taxes (panel A), the share that requested deductions (panel B), and the share that reported positive amounts of foreign income without requesting any deductions (panel C). 


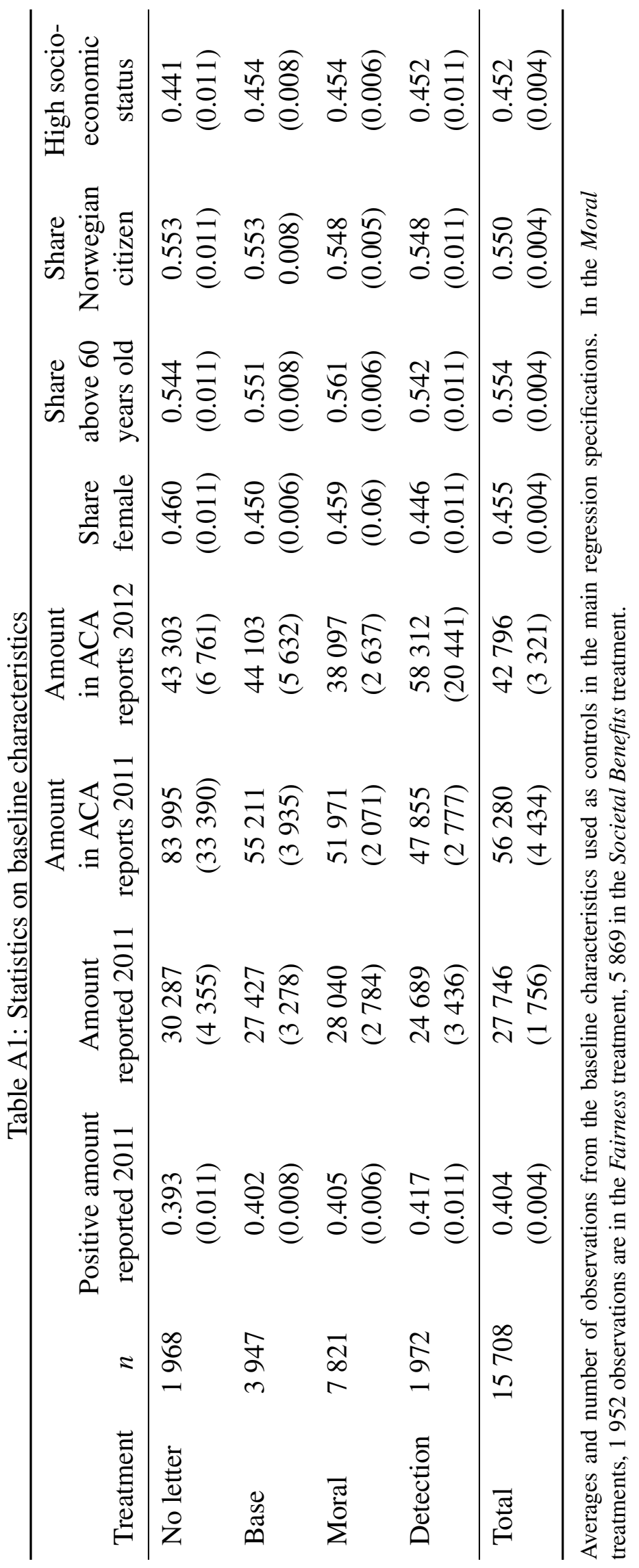




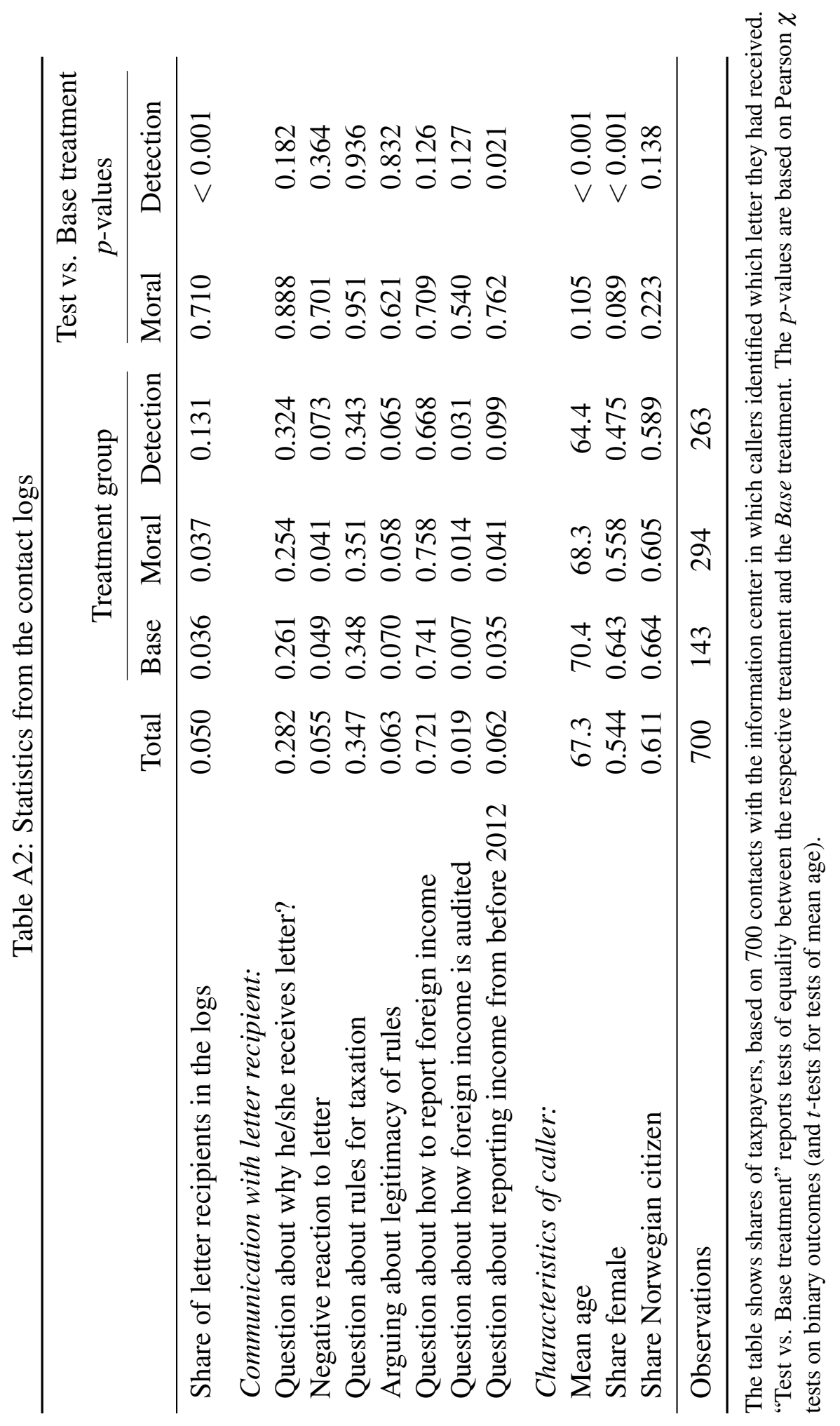


Table A3: Treatment effects: All subtreatments

\begin{tabular}{|c|c|c|c|c|}
\hline & \multicolumn{2}{|c|}{ Level reported (in NOK) } & \multicolumn{2}{|c|}{ Reporting positive amount } \\
\hline & (1) & (2) & (3) & (4) \\
\hline No letter & $\begin{array}{l}-3188.0^{*} \\
(1643.3)\end{array}$ & $\begin{array}{c}-4339.0 \\
(2734.9)\end{array}$ & $\begin{array}{c}-0.086^{* * *} \\
(0.0095)\end{array}$ & $\begin{array}{c}-0.083^{* * *} \\
(0.0091)\end{array}$ \\
\hline Fairness & $\begin{array}{l}15158.5^{*} \\
(8861.2)\end{array}$ & $\begin{array}{c}10372.3^{* *} \\
(4042.0)\end{array}$ & $\begin{array}{c}0.031^{* * *} \\
(0.011)\end{array}$ & $\begin{array}{c}0.030^{* * *} \\
(0.011)\end{array}$ \\
\hline Societal Benefits (SB) & $\begin{array}{c}9389.6 \\
(6791.9)\end{array}$ & $\begin{array}{c}9389.3 \\
(6980.4)\end{array}$ & $\begin{array}{l}0.0055 \\
(0.011)\end{array}$ & $\begin{array}{c}-0.00073 \\
(0.011)\end{array}$ \\
\hline Visual SB & $\begin{array}{c}3365.1 \\
(2492.2)\end{array}$ & $\begin{array}{l}6107.5^{* *} \\
(3107.5)\end{array}$ & $\begin{array}{l}0.0066 \\
(0.011)\end{array}$ & $\begin{array}{l}0.0052 \\
(0.011)\end{array}$ \\
\hline Visual and verbal SB & $\begin{array}{c}2931.0 \\
(2048.5)\end{array}$ & $\begin{array}{c}3650.3 \\
(2688.6)\end{array}$ & $\begin{array}{c}0.014 \\
(0.011)\end{array}$ & $\begin{array}{c}0.012 \\
(0.011)\end{array}$ \\
\hline Detection & $\begin{array}{l}9199.6^{* *} \\
(4385.9)\end{array}$ & $\begin{array}{c}10350.8^{* *} \\
(4703.0)\end{array}$ & $\begin{array}{l}0.13^{* * *} \\
(0.012)\end{array}$ & $\begin{array}{l}0.13^{* * *} \\
(0.012)\end{array}$ \\
\hline Baseline value & & $\begin{array}{l}0.42^{* *} \\
(0.20)\end{array}$ & & $\begin{array}{c}0.16^{* * *} \\
(0.0073)\end{array}$ \\
\hline ACA-report baseline & & $\begin{array}{c}0.00091 \\
(0.0035)\end{array}$ & & $\begin{array}{l}0.022^{*} \\
(0.013)\end{array}$ \\
\hline ACA-report follow-up & & $\begin{array}{c}0.010 \\
(0.0073)\end{array}$ & & $\begin{array}{c}0.029 \\
(0.024)\end{array}$ \\
\hline Female & & $\begin{array}{c}6808.3^{*} \\
(3649.0)\end{array}$ & & $\begin{array}{l}0.052^{* * *} \\
(0.0063)\end{array}$ \\
\hline Age $>60 \mathrm{yrs}$ & & $\begin{array}{l}9123.2^{*} \\
(5247.0)\end{array}$ & & $\begin{array}{c}0.22^{* * *} \\
(0.0075)\end{array}$ \\
\hline Norwegian citizen & & $\begin{array}{c}2686.8 \\
(3281.0)\end{array}$ & & $\begin{array}{l}0.00026 \\
(0.0068)\end{array}$ \\
\hline High SES & & $\begin{array}{c}4637.9 \\
(5278.2)\end{array}$ & & $\begin{array}{l}0.038^{* * *} \\
(0.0070)\end{array}$ \\
\hline Constant & $\begin{array}{c}11342.9^{* * *} \\
(999.7)\end{array}$ & $\begin{array}{l}-12368.9 \\
(7535.1)\end{array}$ & $\begin{array}{c}0.20^{* * *} \\
(0.0063)\end{array}$ & $\begin{array}{c}-0.030^{* * *} \\
(0.0081)\end{array}$ \\
\hline F-test $p$ on SB & 0.65 & 0.59 & 0.79 & 0.59 \\
\hline Observations & 15708 & 15708 & 15708 & 15708 \\
\hline$R^{2}$ & 0.001 & 0.231 & 0.019 & 0.102 \\
\hline
\end{tabular}

The table reports regressions using the same specifications as in the main Tables 4 and 5 , but with the set of treatments expanded to include all sub-treatments. "Baseline value" is the baseline value of the dependent variable. The F-test refers to the hypothesis that all coefficients for the Societal Benefits treatments are the same. For columns (3) and (4), ACA-reports for the baseline year and follow-up year have been scaled in units of 1000000 NOK. Robust standard errors in parentheses $\left({ }^{*}: p<0.1,{ }^{* *}: p<0.05,{ }^{* * *}: p<0.01\right)$. 
Table A4: Independent survey of letters conducted in 2014

\begin{tabular}{|c|c|c|c|c|c|}
\hline & $\begin{array}{c}\text { Most } \\
\text { people } \\
\text { report } \\
\text { correctly }\end{array}$ & $\begin{array}{c}\text { Taxes } \\
\text { finance } \\
\text { important } \\
\text { services }\end{array}$ & $\begin{array}{c}\text { Probability } \\
\text { of no } \\
\text { detection }\end{array}$ & $\begin{array}{c}\text { Treatment } \\
\text { question }\end{array}$ & $\begin{array}{c}\text { Not-treatment } \\
\text { questions }\end{array}$ \\
\hline Fairness & $\begin{array}{c}0.053 \\
(0.089)\end{array}$ & $\begin{array}{l}-0.013 \\
(0.085)\end{array}$ & $\begin{array}{l}0.0081 \\
(0.091)\end{array}$ & & \\
\hline Societal Benefits & $\begin{array}{l}-0.015 \\
(0.090)\end{array}$ & $\begin{array}{c}0.096 \\
(0.086)\end{array}$ & $\begin{array}{l}-0.050 \\
(0.090)\end{array}$ & & \\
\hline Detection & $\begin{array}{l}-0.070 \\
(0.088)\end{array}$ & $\begin{array}{c}0.063 \\
(0.085)\end{array}$ & $\begin{array}{c}0.12 \\
(0.090)\end{array}$ & & \\
\hline Treated & & & & $\begin{array}{l}0.089^{*} \\
(0.053)\end{array}$ & $\begin{array}{l}-0.013 \\
(0.048)\end{array}$ \\
\hline Female & $\begin{array}{l}0.0093 \\
(0.063)\end{array}$ & $\begin{array}{l}-0.034 \\
(0.060)\end{array}$ & $\begin{array}{l}0.20^{* * *} \\
(0.064)\end{array}$ & $\begin{array}{c}0.064 \\
(0.052)\end{array}$ & $\begin{array}{c}0.020 \\
(0.045)\end{array}$ \\
\hline Norwegian citizen & $\begin{array}{c}0.11 \\
(0.067)\end{array}$ & $\begin{array}{l}-0.034 \\
(0.064)\end{array}$ & $\begin{array}{l}-0.15^{* *} \\
(0.068)\end{array}$ & $\begin{array}{l}-0.027 \\
(0.053)\end{array}$ & $\begin{array}{l}-0.025 \\
(0.048)\end{array}$ \\
\hline Age & $\begin{array}{l}-0.00013 \\
(0.0019)\end{array}$ & $\begin{array}{l}0.0042^{* *} \\
(0.0018)\end{array}$ & $\begin{array}{l}0.013^{* * *} \\
(0.0019)\end{array}$ & $\begin{array}{c}0.0067^{* * *} \\
(0.0015)\end{array}$ & $\begin{array}{c}0.0055^{* * *} \\
(0.0014)\end{array}$ \\
\hline Constant & $\begin{array}{c}-0.056 \\
(0.14)\end{array}$ & $\begin{array}{l}-0.24^{*} \\
(0.13)\end{array}$ & $\begin{array}{c}-0.82^{* * *} \\
(0.14)\end{array}$ & $\begin{array}{c}-0.44^{* * *} \\
(0.12)\end{array}$ & $\begin{array}{c}-0.34^{* * *} \\
(0.11)\end{array}$ \\
\hline Observations & 1046 & 1061 & 948 & 1486 & 2274 \\
\hline
\end{tabular}

The table shows responses to questions in a post-intervention survey with 4000 tax subjects (700 from the control group and 3300 from the group with ACA-reports that self-reportered correctly; these groups were not tracked in the survey). They were randomly assigned to receive one of four letters (base, fairness, societal benefits, detection). After reading the letter they were asked to complete a survey. In addition to a set of general questions, they were asked to state the extent to which they agreed with the following statements (scale 1-5, disagree-agree) : A) "Most people report income correctly and comprehensively in their tax returns" and B) "Tax payments finance important public services". Further, they were asked about their subjective detection probability, C) "How probable do you believe it to be that it would be detected if you did not report foreign income (report a number between 0 and $100 \%$ )." $27.2 \%$ of the individuals responded to the survey, with no differences in response rate across treatments (Pearson's chi-squared test, $p=0.401$ ). In the left part of the table, we report responses for each of the three questions (in standard deviations), where "Fairness", "Societal Benefits", and "Detection" are indicator variables taking the value one if the survey participant received the letter used in the corresponding treatment. The effects are estimated relative the the response of the survey participants who received the base letter. "Female" is an indicator variable taking the value one if the survey participant is a female, "Norwegian citizen" is an indicator variable taking the value one if the survey participant is a Norwegian citizen, "Age" is the age of the survey participant (in years). We observe that the individuals systematically respond in line with our assumptions on the issue that was highlighted in the letter they received. We also observe that there is no effect of the moral letters on the subjective detection probability. The effects are not large, but it should be kept in mind that the survey manipulation is weak and the sample mostly consists of individuals who self-reported correctly at baseline. In the right part of the panel, we show that we indeed do find a statistically significant effect of the letters working as intended. In the column "Treatment question", we compare the response to the question that the letter they had received highlighted (for example the response to question $\mathrm{C}$ for the individuals receiving letter C) to the response to the same question by the individuals who had received the base letter, where "Treated" is an indicator variable for whether the respondent received one of the treatment letters or the base letter. Correspondingly, in the column "Not-treatment questions", we compare the responses to the questions that the letter they had received did not highlight (for example the responses on questions $\mathrm{A}$ and $\mathrm{B}$ for the individuals receiving letter $\mathrm{C}$ ) to the responses to the same questions by the individuals who had received the base letter. Robust standard errors clustered on individuals $\left(^{*}: p<0.1,{ }^{* *}: p<0.05,{ }^{* * *}: p<0.01\right)$. 


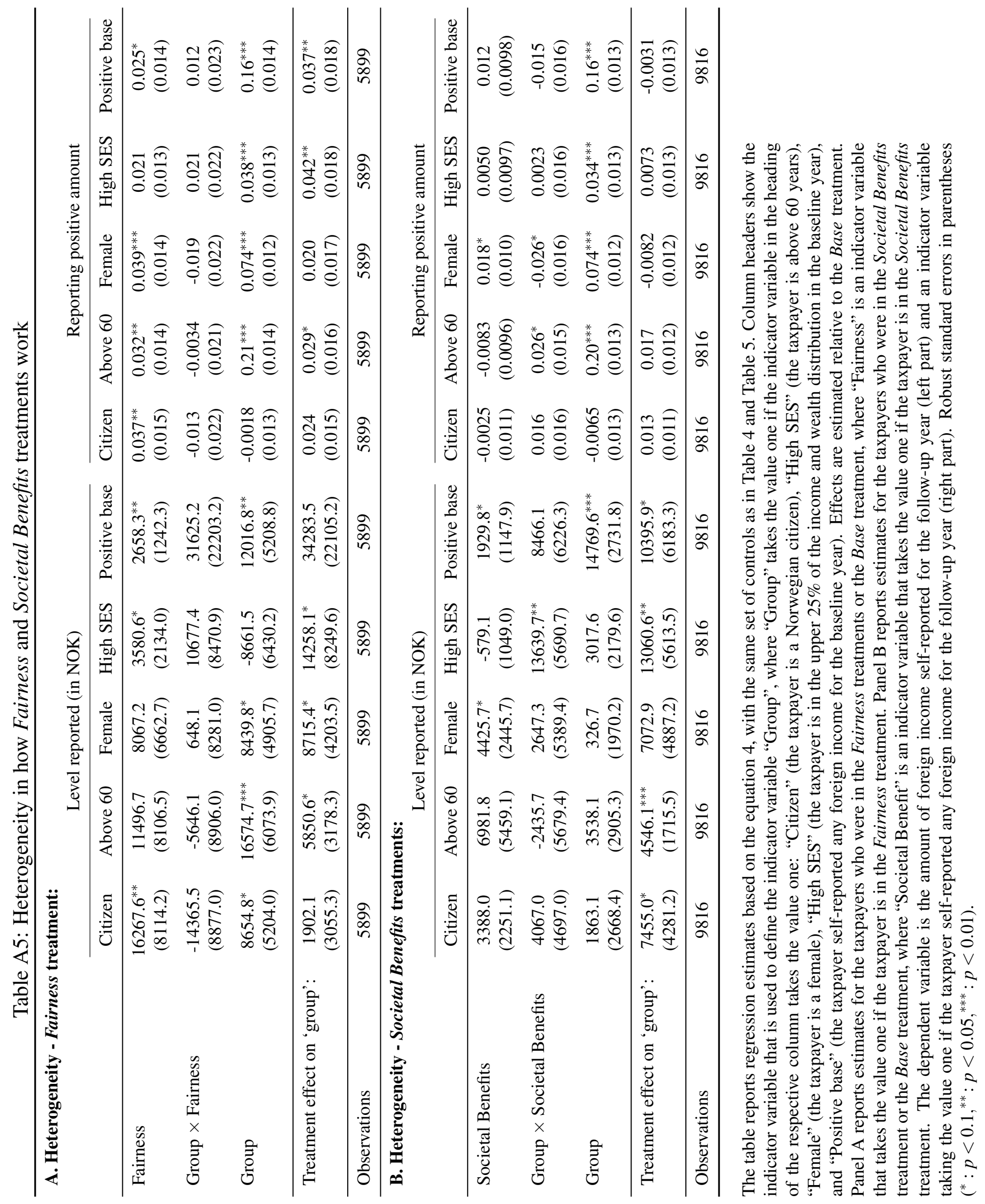


Table A6: Long-term treatment effects on self-reported foreign income

\begin{tabular}{|c|c|c|c|c|c|c|}
\hline & (1) & (2) & (3) & (4) & (5) & (6) \\
\hline No letter & $\begin{array}{c}-3835.3 \\
(4319.8)\end{array}$ & $\begin{array}{l}-3934.9 \\
(4295.7)\end{array}$ & $\begin{array}{l}-1860.3 \\
(3601.2)\end{array}$ & $\begin{array}{l}-1982.4 \\
(3589.0)\end{array}$ & $\begin{array}{c}-1860.3 \\
(3601.1)\end{array}$ & $\begin{array}{l}-1981.7 \\
(3588.8)\end{array}$ \\
\hline Fairness & & & $\begin{array}{c}912.5 \\
(4015.1)\end{array}$ & $\begin{array}{c}-155.7 \\
(3621.8)\end{array}$ & & \\
\hline Societal Benefits & & & $\begin{array}{c}4702.7 \\
(7683.8)\end{array}$ & $\begin{array}{c}4917.6 \\
(7685.1)\end{array}$ & & \\
\hline Detection & & & $\begin{array}{l}-1138.6 \\
(3122.8)\end{array}$ & $\begin{array}{c}-871.7 \\
(3023.9)\end{array}$ & $\begin{array}{l}-1138.6 \\
(3122.7)\end{array}$ & $\begin{array}{c}-872.1 \\
(3023.9)\end{array}$ \\
\hline Moral & & & & & $\begin{array}{c}3756.7 \\
(6007.5)\end{array}$ & $\begin{array}{c}3651.4 \\
(6015.4)\end{array}$ \\
\hline Foreign income baseline & & $\begin{array}{c}0.11^{* *} \\
(0.046)\end{array}$ & & $\begin{array}{c}0.11^{* *} \\
(0.046)\end{array}$ & & $\begin{array}{l}0.11^{* *} \\
(0.046)\end{array}$ \\
\hline ACA-report baseline & & $\begin{array}{c}0.0075 \\
(0.0099)\end{array}$ & & $\begin{array}{c}0.0075 \\
(0.0099)\end{array}$ & & $\begin{array}{c}0.0075 \\
(0.0099)\end{array}$ \\
\hline ACA-report follow-up & & $\begin{array}{c}0.016 \\
(0.010)\end{array}$ & & $\begin{array}{c}0.016 \\
(0.010)\end{array}$ & & $\begin{array}{c}0.016 \\
(0.010)\end{array}$ \\
\hline Female & & $\begin{array}{l}-7501.1 \\
(4684.6)\end{array}$ & & $\begin{array}{l}-7541.2 \\
(4735.6)\end{array}$ & & $\begin{array}{l}-7534.1 \\
(4726.0)\end{array}$ \\
\hline Age $>60$ yrs & & $\begin{array}{c}20551.9^{* * *} \\
(3882.4)\end{array}$ & & $\begin{array}{c}20487.8^{* * *} \\
(3817.4)\end{array}$ & & $\begin{array}{c}20492.5^{* * *} \\
(3822.0)\end{array}$ \\
\hline Norwegian citizen & & $\begin{array}{l}-6216.6^{*} \\
(3633.2)\end{array}$ & & $\begin{array}{l}-6178.3^{*} \\
(3673.7)\end{array}$ & & $\begin{array}{l}-6188.8^{*} \\
(3661.9)\end{array}$ \\
\hline High SES & & $\begin{array}{c}12147.0^{* *} \\
(4997.8)\end{array}$ & & $\begin{array}{c}12125.2^{* *} \\
(4969.4)\end{array}$ & & $\begin{array}{c}12151.4^{* *} \\
(5003.4)\end{array}$ \\
\hline Constant & $\begin{array}{c}25949.9^{* * *} \\
(3256.6)\end{array}$ & $\begin{array}{c}11877.7^{* * *} \\
(2458.8)\end{array}$ & $\begin{array}{c}23974.9^{* * *} \\
(2216.3)\end{array}$ & $\begin{array}{l}9962.5^{* *} \\
(4458.1)\end{array}$ & $\begin{array}{c}23974.9^{* * *} \\
(2216.3)\end{array}$ & $\begin{array}{l}9954.2^{* *} \\
(4465.7)\end{array}$ \\
\hline \multicolumn{3}{|c|}{ F-test $p$ on Moral treatments being equal: } & 0.64 & 0.52 & & \\
\hline Observations & 15708 & 15708 & 15708 & 15708 & 15708 & 15708 \\
\hline$R^{2}$ & 0.000 & 0.006 & 0.000 & 0.006 & 0.000 & 0.006 \\
\hline
\end{tabular}

The table reports regressions based on equation 3 , where the dependent variable is the amount foreign income self-reported for 2013. In columns (1) - (2), the estimated effects are relative to the the pooled sample of all treatment groups; in columns (3)-(6), the estimated effects are relative to the Base treatment. The indicator variables "No letter", "Fairness", "Societal Benefits", and "Detection" take the value one if the taxpayer is in the respective treatment. The indicator variable "Moral" is one if the taxpayer is in the Fairness treatment or the Social Benefits treatment. The reported $F$-test $p$ is for the hypothesis that all Moral treatments have the same effect. Columns (2), (4), and (6) include the following controls: the amount of self-reported foreign income for the baseline year, the amount of foreign income recorded in the ACA-reports for 2011 and 2012, gender, age (an indicator variable taking the value one if the taxpayer is more than 60 years), an indicator variable taking the value one if the tax payer is a Norwegian citizen, and an indicator variable of socio-economic status taking the value one if the taxpayer is in the upper $25 \%$ of the income and wealth distribution in the baseline year. Robust standard errors in parentheses. $\left({ }^{*}: p<0.1,{ }^{* *}: p<0.05,{ }^{* * *}: p<0.01\right)$. 
Table A7: Long-term treatment effects on self-reporting of any foreign income

\begin{tabular}{|c|c|c|c|c|c|c|}
\hline & (1) & (2) & (3) & (4) & (5) & (6) \\
\hline No letter & $\begin{array}{c}-0.038^{* * *} \\
(0.010)\end{array}$ & $\begin{array}{c}-0.033^{* * *} \\
(0.0097)\end{array}$ & $\begin{array}{c}-0.023^{* *} \\
(0.012)\end{array}$ & $\begin{array}{l}-0.020^{*} \\
(0.011)\end{array}$ & $\begin{array}{c}-0.023^{* *} \\
(0.012)\end{array}$ & $\begin{array}{l}-0.020^{*} \\
(0.011)\end{array}$ \\
\hline Fairness & & & $\begin{array}{c}0.016 \\
(0.012)\end{array}$ & $\begin{array}{c}0.014 \\
(0.012)\end{array}$ & & \\
\hline Societal Benefits & & & $\begin{array}{c}0.0037 \\
(0.0090)\end{array}$ & $\begin{array}{c}-0.00032 \\
(0.0085)\end{array}$ & & \\
\hline Detection & & & $\begin{array}{c}0.076^{* * *} \\
(0.013)\end{array}$ & $\begin{array}{c}0.076^{* * *} \\
(0.012)\end{array}$ & $\begin{array}{c}0.076^{* * *} \\
(0.013)\end{array}$ & $\begin{array}{c}0.076^{* * *} \\
(0.012)\end{array}$ \\
\hline Moral & & & & & $\begin{array}{c}0.0068 \\
(0.0085)\end{array}$ & $\begin{array}{c}0.0033 \\
(0.0081)\end{array}$ \\
\hline 2011 outcome & & $\begin{array}{c}0.13^{* * *} \\
(0.0077)\end{array}$ & & $\begin{array}{c}0.13^{* * *} \\
(0.0076)\end{array}$ & & $\begin{array}{c}0.13^{* * *} \\
(0.0076)\end{array}$ \\
\hline ACA-report baseline & & $\begin{array}{c}0.013 \\
(0.021)\end{array}$ & & $\begin{array}{c}0.013 \\
(0.021)\end{array}$ & & $\begin{array}{c}0.013 \\
(0.021)\end{array}$ \\
\hline ACA-report follow-up & & $\begin{array}{c}0.044 \\
(0.031)\end{array}$ & & $\begin{array}{c}0.043 \\
(0.032)\end{array}$ & & $\begin{array}{c}0.043 \\
(0.032)\end{array}$ \\
\hline Female & & $\begin{array}{l}0.023^{* * *} \\
(0.0068)\end{array}$ & & $\begin{array}{l}0.023^{* * *} \\
(0.0068)\end{array}$ & & $\begin{array}{l}0.023^{* * *} \\
(0.0068)\end{array}$ \\
\hline Age $>60 \mathrm{yrs}$ & & $\begin{array}{c}0.31^{* * *} \\
(0.0080)\end{array}$ & & $\begin{array}{c}0.31^{* * *} \\
(0.0079)\end{array}$ & & $\begin{array}{c}0.31^{* * *} \\
(0.0080)\end{array}$ \\
\hline Norwegian citizen & & $\begin{array}{c}-0.061^{* * *} \\
(0.0074)\end{array}$ & & $\begin{array}{c}-0.061^{* * *} \\
(0.0074)\end{array}$ & & $\begin{array}{c}-0.061^{* * *} \\
(0.0074)\end{array}$ \\
\hline High SES & & $\begin{array}{c}0.017^{* *} \\
(0.0075)\end{array}$ & & $\begin{array}{c}0.017^{* *} \\
(0.0075)\end{array}$ & & $\begin{array}{c}0.017^{* *} \\
(0.0075)\end{array}$ \\
\hline Constant & $\begin{array}{c}0.27^{* * *} \\
(0.0038)\end{array}$ & $\begin{array}{l}0.057^{* * *} \\
(0.0074)\end{array}$ & $\begin{array}{c}0.25^{* * *} \\
(0.0069)\end{array}$ & $\begin{array}{l}0.044^{* * *} \\
(0.0092)\end{array}$ & $\begin{array}{c}0.25^{* * *} \\
(0.0069)\end{array}$ & $\begin{array}{l}0.044^{* * *} \\
(0.0092)\end{array}$ \\
\hline \multicolumn{3}{|c|}{ F-test $p$ on Moral treatments being equal: } & 0.27 & 0.18 & & \\
\hline $\begin{array}{l}\text { Observations } \\
R^{2}\end{array}$ & $\begin{array}{l}15708 \\
0.001\end{array}$ & $\begin{array}{l}15708 \\
0.103\end{array}$ & $\begin{array}{l}15708 \\
0.004\end{array}$ & $\begin{array}{l}15708 \\
0.106\end{array}$ & $\begin{array}{l}15708 \\
0.004\end{array}$ & $\begin{array}{l}15708 \\
0.106\end{array}$ \\
\hline
\end{tabular}

The table reports regressions based on equation 3. where the dependent variable is an indicator variable taking the value one if the taxpayer self-reports any foreign income reported in 2013. Estimated effects are relative to the Base treatment. The indicator variables "No letter", "Fairness", "Societal Benefits", and "Detection" take the value one if the taxpayer is in the respective treatment. The indicator variable "Moral" is one if the taxpayer is in the Fairness treatment or the Social Benefits treatment. The reported $F$-test $p$ is for the hypothesis that all Moral treatments have the same effect. Columns (2), (4), and (6) include the following controls: an indicator variable taking the value one if the taxpayer self-reported any foreign income for the baseline year, the amount of foreign income recorded in the ACA-reports for 2011 and 2012 (scaled in units of 1000 $000 \mathrm{NOK}$ ), gender, age (an indicator variable taking the value one if the taxpayer is more than 60 years), an indicator variable taking the value one if the tax payer is a Norwegian citizen, and an indicator variable of socio-economic status taking the value one if the taxpayer is in the upper $25 \%$ of the income and wealth distribution in the baseline year. Robust standard errors in parentheses. $\left({ }^{*}: p<0.1,{ }^{* *}: p<0.05,{ }^{* * *}: p<0.01\right)$. 
Table A8: Long-term treatment effects on self-reported foreign income: Various subsamples

\begin{tabular}{|c|c|c|c|c|c|c|c|c|}
\hline Estimating sample: & \multicolumn{4}{|c|}{ Level reported (in NOK) } & \multicolumn{4}{|c|}{ Reporting positive amount } \\
\hline No letter & $\begin{array}{l}-1981.7 \\
(3588.8)\end{array}$ & $\begin{array}{c}-405.7 \\
(4255.3)\end{array}$ & $\begin{array}{c}3568.7 \\
(4715.9)\end{array}$ & $\begin{array}{c}3380.5 \\
(4896.1)\end{array}$ & $\begin{array}{l}-0.020^{*} \\
(0.011)\end{array}$ & $\begin{array}{l}0.0013 \\
(0.015)\end{array}$ & $\begin{array}{c}0.011 \\
(0.013)\end{array}$ & $\begin{array}{c}0.030^{*} \\
(0.017)\end{array}$ \\
\hline Detection & $\begin{array}{c}-872.1 \\
(3023.9)\end{array}$ & $\begin{array}{c}335.4 \\
(4212.8)\end{array}$ & $\begin{array}{c}-864.8 \\
(3024.7)\end{array}$ & $\begin{array}{c}320.9 \\
(4214.6)\end{array}$ & $\begin{array}{c}0.076^{* * *} \\
(0.012)\end{array}$ & $\begin{array}{c}0.054^{* * *} \\
(0.015)\end{array}$ & $\begin{array}{c}0.076^{* * *} \\
(0.012)\end{array}$ & $\begin{array}{c}0.054^{* * *} \\
(0.015)\end{array}$ \\
\hline Moral & $\begin{array}{c}3651.4 \\
(6015.4)\end{array}$ & $\begin{array}{c}7736.3 \\
(9734.7)\end{array}$ & $\begin{array}{c}3646.1 \\
(6016.5)\end{array}$ & $\begin{array}{c}7725.0 \\
(9739.1)\end{array}$ & $\begin{array}{c}0.0033 \\
(0.0081)\end{array}$ & $\begin{array}{l}0.0053 \\
(0.011)\end{array}$ & $\begin{array}{c}0.0033 \\
(0.0081)\end{array}$ & $\begin{array}{l}0.0052 \\
(0.011)\end{array}$ \\
\hline Baseline value & $\begin{array}{l}0.11^{* *} \\
(0.046)\end{array}$ & $\begin{array}{l}0.072^{*} \\
(0.040)\end{array}$ & $\begin{array}{l}0.11^{* *} \\
(0.046)\end{array}$ & $\begin{array}{l}0.070^{*} \\
(0.040)\end{array}$ & $\begin{array}{c}0.13^{* * *} \\
(0.0076)\end{array}$ & $\begin{array}{c}0.10^{* * *} \\
(0.0095)\end{array}$ & $\begin{array}{c}0.13^{* * *} \\
(0.0078)\end{array}$ & $\begin{array}{l}0.100^{* * *} \\
(0.0097)\end{array}$ \\
\hline Female & $\begin{array}{l}-7534.1 \\
(4726.0)\end{array}$ & $\begin{array}{l}-7505.2 \\
(6903.4)\end{array}$ & $\begin{array}{l}-7776.1 \\
(4915.3)\end{array}$ & $\begin{array}{l}-7740.0 \\
(7123.3)\end{array}$ & $\begin{array}{l}0.023^{* * *} \\
(0.0068)\end{array}$ & $\begin{array}{l}0.028^{* * *} \\
(0.0088)\end{array}$ & $\begin{array}{l}0.023^{* * *} \\
(0.0070)\end{array}$ & $\begin{array}{l}0.028^{* * *} \\
(0.0089)\end{array}$ \\
\hline Age $>60$ yrs & $\begin{array}{c}20492.5^{* * *} \\
(3822.0)\end{array}$ & $\begin{array}{c}29164.4^{* * *} \\
(5879.1)\end{array}$ & $\begin{array}{c}20951.2^{* * *} \\
(3970.3)\end{array}$ & $\begin{array}{c}29740.1^{* * *} \\
(6094.8)\end{array}$ & $\begin{array}{c}0.31^{* * *} \\
(0.0080)\end{array}$ & $\begin{array}{l}0.37^{* * *} \\
(0.010)\end{array}$ & $\begin{array}{c}0.31^{* * *} \\
(0.0081)\end{array}$ & $\begin{array}{l}0.37^{* * *} \\
(0.010)\end{array}$ \\
\hline Norwegian citizen & $\begin{array}{l}-6188.8^{*} \\
(3661.9)\end{array}$ & $\begin{array}{c}2537.8 \\
(6781.3)\end{array}$ & $\begin{array}{l}-6210.8 \\
(3820.3)\end{array}$ & $\begin{array}{c}2735.2 \\
(7008.8)\end{array}$ & $\begin{array}{c}-0.061^{* * *} \\
(0.0074)\end{array}$ & $\begin{array}{c}-0.050^{* * *} \\
(0.0096)\end{array}$ & $\begin{array}{c}-0.061^{* * *} \\
(0.0076)\end{array}$ & $\begin{array}{c}-0.051^{* * *} \\
(0.0098)\end{array}$ \\
\hline High SES & $\begin{array}{c}12151.4^{* *} \\
(5003.4)\end{array}$ & $\begin{array}{l}14571.0^{*} \\
(8583.9)\end{array}$ & $\begin{array}{c}12558.2^{* *} \\
(5218.1)\end{array}$ & $\begin{array}{l}14929.1^{*} \\
(8864.9)\end{array}$ & $\begin{array}{l}0.017^{* *} \\
(0.0075)\end{array}$ & $\begin{array}{c}0.020^{* *} \\
(0.0100)\end{array}$ & $\begin{array}{c}0.019^{* *} \\
(0.0077)\end{array}$ & $\begin{array}{l}0.022^{* *} \\
(0.010)\end{array}$ \\
\hline
\end{tabular}

The table reports regressions using the same specification as in Table A6 and Table A7, where Columns 1 and 5 correspond to column 6 in Table A6 and Table A7. The remaining columns exclude participants with baseline foreign income recorded in ACA-reports in a range that might imply that they were targeted for differentiated follow $(A)$ or participants that were part of the survey follow $(B)$. Columns $A+B$ exclude both groups. Robust standard errors in parentheses $\left({ }^{*}: p<0.1,{ }^{* *}: p<0.05,{ }^{* * *}: p<0.01\right)$. 


\section{B Appendix for online publication only: Translation of all treatment letters}

Figure B1: Base letter (I)

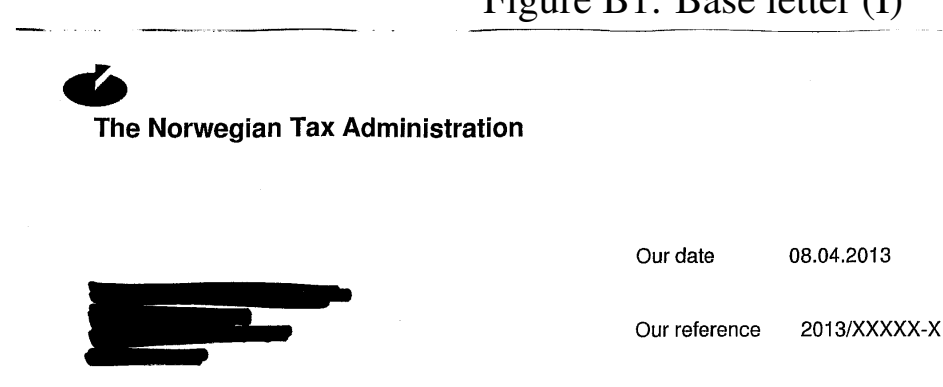

Information about the tax return for the income year $\mathbf{2 0 1 2}$

The Norwegian economy is becoming more internationalised, and an increasing number of Norwegian taxpayers receive income and have assets abroad. You are receiving this letter because The Norwegian Tax Administration would like to inform you about how this type of income is taxed and how it should be reported.

If you are a tax resident of Norway, you are liable to pay taxes to Norway even on foreign income and foreign assets, unless otherwise specified in the tax treaties Norway has entered into with other countries. Information about tax treaties and the rules that apply for taxation of foreign income and foreign assets is available at the homepage of The Norwegian Tax Administration www.skatteetaten.no. You can also contact us by telephone 21497394 (opening hours: $08.00-15.30$ ).

When you receive the pre-completed tax return, you must check the information that it contains. If all information is correct and complete, you do not need to make any changes. The pre-completed tax return will typically not contain information about foreign income and foreign assets. You therefore need to report all income, all assets and all taxes paid in foreign countries. More information is available on www.skatteetaten.no/A-rettledninger.

Regards

The Norwegian Tax Administration 
Figure B2: Base letter (II)

The Norwegian Tax Administration

Our date $\quad 08.04 .2013$

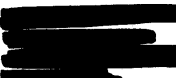

Our reference 2013/XXXXX-X

Information about the tax return for the income year 2012

The Norwegian economy is becoming more internationalised, and an increasing number of Norwegian taxpayers receive income and have assets abroad. The purpose of this letter is to provide information about how this type of income is taxed and how it should be reported.

If a person is a tax resident of Norway, he or she is liable to pay taxes to Norway even on foreign income and foreign assets, unless otherwise specified in the tax treaties Norway has entered into with other countries. Information about tax treaties and the rules that apply for taxation of foreign income and foreign assets is available at the homepage of The Norwegian Tax Administration www.skatteetaten.no. The Norwegian Tax Administration can also be contacted by telephone 21497394 (opening hours: $08.00-15.30$ ).

Information contained in the pre-completed tax return, must be checked. If all information is correct and complete, there is no need to make any changes. The pre-completed tax return will typically not contain information about foreign income and foreign assets. All income, all assets and all taxes paid in foreign countries should therefore be reported. More information is available on www.skatteetaten.no/G-rettledninger.

Regards

The Norwegian Tax Administration 
Figure B3: Fairness letter

The Norwegian Tax Administration

Our date $\quad 08.04 .2013$

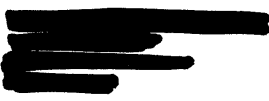

Our reference 2013/XXXXX-X

Information about the tax return for the income year 2012

The Norwegian economy is becoming more internationalised, and an increasing number of Norwegian taxpayers receive income and have assets abroad. You are receiving this letter because The Norwegian Tax Administration would like to inform you about how this type of income is taxed and how it should be reported. The great majority report information about their income and assets in Norway correctly and completely. In order to treat all taxpayers fairly, it is therefore important that foreign income and foreign assets are reported in the same manner.

If you are a tax resident of Norway, you are liable to pay taxes to Norway even on foreign income and foreign assets, unless otherwise specified in the tax treaties Norway has entered into with other countries. Information about tax treaties and the rules that apply for taxation of foreign income and foreign assets is available at the homepage of The Norwegian Tax Administration www.skatteetaten.no. You can also contact us by telephone 21497394
Ad (opening hours: $08.00-15.30$ ).

When you receive the pre-completed tax return, you must check the information that it contains. If all information is correct and complete, you do not need to make any changes. The pre-completed tax return will typically not contain information about foreign income and foreign assets. You therefore need to report all income, all assets and all taxes paid in foreign countries. More information is available on www.skatteetaten.no/C-rettledninger.

Regards

The Norwegian Tax Administration 
Figure B4: Societal benefits letter (I)

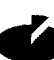

The Norwegian Tax Administration

\author{
Our date \\ 08.04 .2013 \\ Our reference $\quad 2013 / X X X X X-X$
}

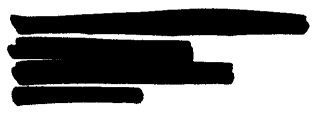

\title{
Information about the tax return for the income year 2012
}

The Norwegian economy is becoming more internationalised, and an increasing number of Norwegian taxpayers receive income and have assets abroad. You are receiving this letter because The Norwegian Tax Administration would like to inform you about how this type of income is taxed and how it should be reported. Your tax payment contributes to the funding of publicly financed services in education, health and other important sectors of society.

If you are a tax resident of Norway, you are liable to pay taxes to Norway even on foreign income and foreign assets, unless otherwise specified in the tax treaties Norway has entered into with other countries. Information about tax treaties and the rules that apply for taxation of foreign income and foreign assets is available at the homepage of The Norwegian Tax Administration www.skatteetaten.no. You can also contact us by telephone 21497394 (opening hours: $08.00-15.30$ ).

When you receive the pre-completed tax return, you must check the information that it contains. If all information is correct and complete, you do not need to make any changes. The pre-completed tax return will typically not contain information about foreign income and foreign assets. You therefore need to report all income, all assets and all taxes paid in foreign countries. More information is available on www.skatteetaten.no/D-rettledninger.

Regards

The Norwegian Tax Administration 
Figure B5: Societal benefits letter (II)

The Norwegian Tax Administration

\begin{tabular}{lll} 
Our date & 08.04 .2013 \\
& Our reference & $2013 / X X X X X-X$ \\
\hline & &
\end{tabular}

Information about the tax return for the income year 2012

The Norwegian economy is becoming more internationalised, and an increasing number of Norwegian taxpayers receive income and have assets abroad. You are receiving this letter because The Norwegian Tax Administration would like to inform you about how this type of income is taxed and how it should be reported.

If you are a tax resident of Norway, you are liable to pay taxes to Norway even on foreign income and foreign assets, unless otherwise specified in the tax treaties Norway has entered into with other countries. Information about tax treaties and the rules that apply for taxation of foreign income and foreign assets is available at the homepage of The Norwegian Tax Administration www.skatteetaten.no. You can also contact us by telephone 21497394 (opening hours: $08.00-15.30$ ).

When you receive the pre-completed tax return, you must check the information that it contains. If all information is correct and complete, you do not need to make any changes. The pre-completed tax return will typically not contain information about foreign income and foreign assets. You therefore need to report all income, all assets and all taxes paid in foreign countries. More information is available on www.skatteetaten.no/H-rettledninger.

Regards

The Norwegian Tax Administration

This letter is the same as base letter (I), Figure B1, and it was combined with the attachment, Figure B6. 

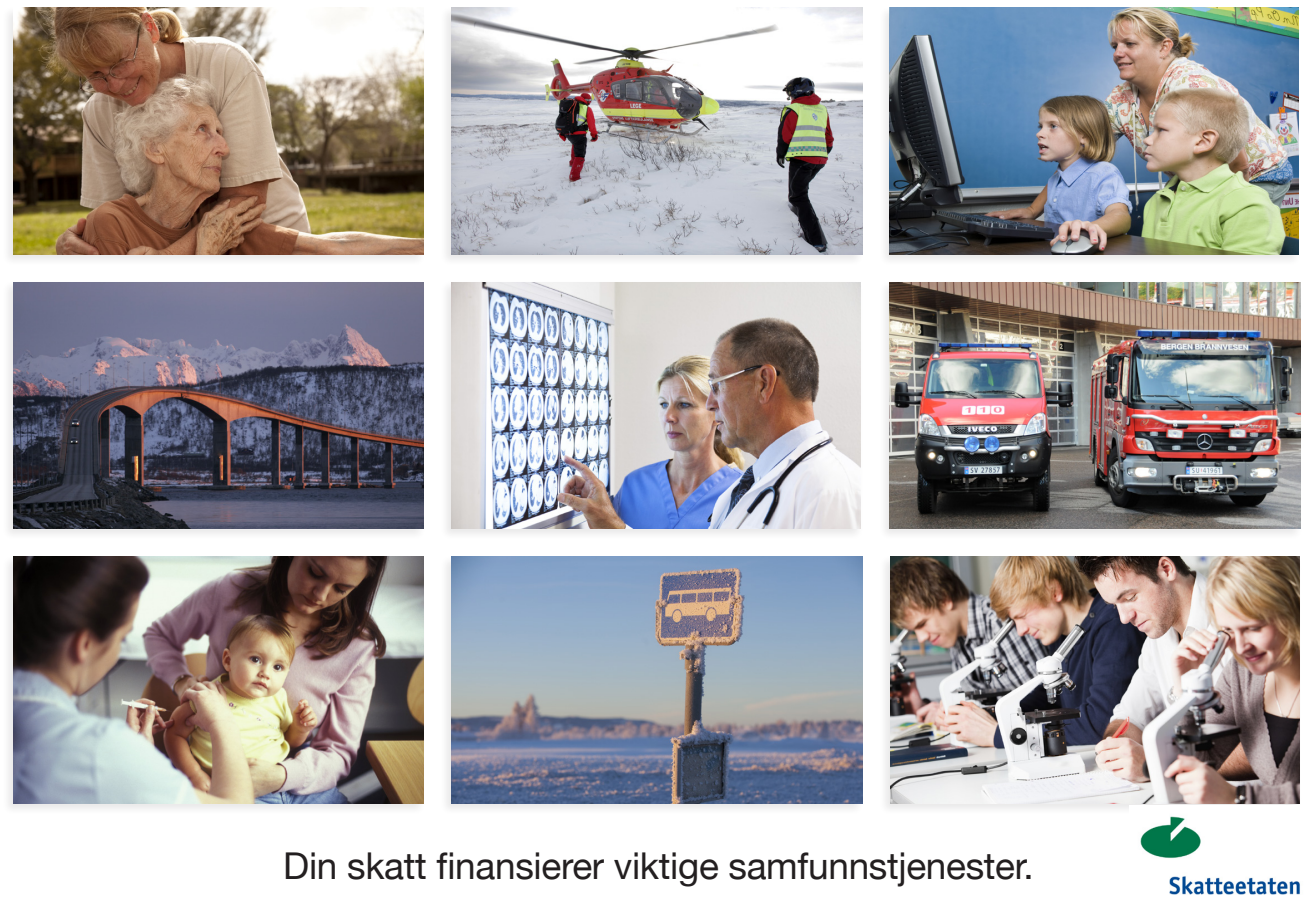

Din skatt finansierer viktige samfunnstjenester.

Figure B6: Attachment to Societal Benefits letters

The subtitle to the picture states that "Your taxes finance important public services." Attachments were sent in Norwegian to all recipients of the relevant treatment letters. 
Figure B7: Societal benefits letter (III)

\section{The Norwegian Tax Administration}

$\begin{array}{lll}\text { Our date } & 08.04 .2013 \\ & \text { Our reference } & \text { 2013/XXXXX-X }\end{array}$

Information about the tax return for the income year 2012

The Norwegian economy is becoming more internationalised, and an increasing number of Norwegian taxpayers receive income and have assets abroad. You are receiving this letter because The Norwegian Tax Administration would like to inform you about how this type of income is taxed and how it should be reported. Your tax payment contributes to the funding of publicly financed services in education, health and other important sectors of society.

If you are a tax resident of Norway, you are liable to pay taxes to Norway even on foreign income and foreign assets, unless otherwise specified in the tax treaties Norway has entered into with other countries. Information about tax treaties and the rules that apply for taxation of foreign income and foreign assets is available at the homepage of The Norwegian Tax Administration www.skatteetaten.no. You can also contact us by telephone 21497394 (opening hours: $08.00-15.30$ ).

When you receive the pre-completed tax return, you must check the information that it contains. If all information is correct and complete, you do not need to make any changes. The pre-completed tax return will typically not contain information about foreign income and foreign assets. You therefore need to report all income, all assets and all taxes paid in foreign countries. More information is available on www.skatteetaten.no/l-rettledninger.

Regards

The Norwegian Tax Administration

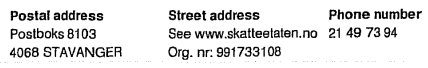

This letter is the same as societal benefits (I) letter, Figure B4, and it was combined with the attachment, Figure B6 
Figure B8: Detection letter

The Norwegian Tax Administration

\begin{tabular}{lll} 
& Our date & 08.04 .2013 \\
\hline & Our reference & $2013 / X X X X X-X$
\end{tabular}

Information about the tax return for the income year 2012

The Norwegian Tax Administration received information that you have had income and/or assets abroad in previous years. You are receiving this letter because The Norwegian Tax Administration would like to inform you about how this type of income is taxed and how it should be reported.

If you are a tax resident of Norway, you are liable to pay taxes to Norway even on foreign income and foreign assets, unless otherwise specified in the tax treaties Norway has entered into with other countries. Information about tax treaties and the rules that apply for taxation of foreign income and foreign assets is available at the homepage of The Norwegian Tax Administration www.skatteetaten.no. You can also contact us by telephone 21497394 (opening hours: $08.00-15.30$ )

When you receive the pre-completed tax return, you must check the information that it contains. If all information is correct and complete, you do not need to make any changes. The pre-completed tax return will typically not contain information about foreign income and foreign assets. You therefore need to report all income, all assets and all taxes paid in foreign countries. More information is available on www.skatteetaten.no/E-rettledninger.

Regards

The Norwegian Tax Administration 